PNL-9053

UC-721

\title{
Review and Assessment
}

of Technologies for the

Separation of Strontium from

Alkaline and Acidic Media

\author{
R. J. Orth \\ D. E. Kurath
}

January 1994

\section{Prepared for}

Westinghouse Hanford Company

under a Related Services Agreement

with the U.S. Department of Energy

Contract DE-AC06-76RLO 1830

Pacific Northwest Laboratory

Operated for the U.S. Department of Energy

by Battelle Memorial Institute 


\title{
DISCLAIMER
}

This report was prepared as an account of work sponsored by an agency of the United States Government. Neither the United States Government nor any agency thereof, nor Battelle Memorial Institute, nor any of their employees, makes any warranty, expressed or implied, or assumes any legal liability or responsibility for the accuracy, completeness, or usefulness of any information, apparatus, product, or process disclosed, or represents that its use would not infringe privately owned rights. Reference herein to any specific commercial product, process, or service by trade name, trademark, manufacturer, or otherwise does not necessarily constitute or imply its endorsement, recommendation, or favoring by the United States Government or any agency thereof, or Battelle Memorial Institute. The views and opinions of authors expressed herein do not necessarily state or reflect those of the United States Government or any agency thereof.

\author{
PACIFIC NORTHWEST LABORATORY \\ operated by \\ BATTELLE MEMORIAL INSTITUTE \\ for the \\ UNITED STATES DEPARTMENT OF ENERGY \\ under Contract DE-ACO6-76RLO 1830
}

Printed in the United States of America

Available to DOE and DOE contractors from the

Office of Scientific and Technical Information, P.O. Box 62, Oak Ridge, TN 37831; prices available from (615) 576-8401. FTS 626-8401.

Available to the public from the National Technical Information Service, U.S. Department of Commerce, 5285 Port Royal Rd., Springfield, VA 22161. 
Review and Assessment of Technologies for the Separation of Strontium from Alkaline and Acidic Media

\author{
R. J. Orth \\ D. E. Kurath
}

January 1994

\begin{abstract}
Prepared for
Westinghouse Hanford Company under a Related Services Agreement with the U.S. Department of Energy Contract DE-AC06-76RLO 1830
\end{abstract}




\section{Summary}

A literature survey has been conducted to identify and evaluate methods for the separation of strontium from acidic and alkaline media as applied to Hanford tank waste. The most promising methods of solvent extraction, precipitation, and ion exchange are listed in Table S.1.

The following criteria were used for evaluating the separation methods:

- Appreciable strontium removal must be demonstrated (i.e., strontium decontamination factors on the order of $5 \times 10^{4}$ for acid-side processing, and $2 \times 10^{3}$ for alkaline-side processing).

- Strontium selectivity over bulk components must be demonstrated.

- The method must show promise for evolving into a practical and fairly simple process.

- The process should be safe to operate.

- The method must be robust (i.e., capable of separating strontium from various waste types).

- Secondary waste generation must be minimized.

- The method must show resistance to radiation damage.

The methods listed in Table S.1 did not necessarily satisfy all of the above criteria; thus, key areas requiring further development are also given for each method. Less promising solvent extraction, precipitation, and ion exchange methods were also identified; areas for potential development are included in this report. 
Table S.1. Promising Strontium Separation Methods as Applied to Hanford Waste

\begin{tabular}{|c|c|c|}
\hline Separation Method & Attributes Based on Available Data & Required Further Development \\
\hline \multicolumn{3}{|c|}{ Solvent Extraction (acid-side strontium removal) } \\
\hline Crown ether (e.g., SREX) & $\begin{array}{l}\text { Good strontium separation. } \\
\text { Shows potential for evolving into a practical } \\
\text { process. } \\
\text { Resistance to radiation damage has been } \\
\text { indicated. } \\
\text { Has undergone a fair amount of development } \\
\text { (e.g., tested as continuous bench system, } \\
\text { tested on actual waste). }\end{array}$ & $\begin{array}{l}\text { Test on simulated and actual waste to better } \\
\text { determine process robustness as related to } \\
\text { Sr separation and selectivity. } \\
\text { Look into the possibility of using this } \\
\text { system for alkaline-side strontium removal. }\end{array}$ \\
\hline $\begin{array}{l}\text { Cobalt dicarbolide and } \\
\text { chlorinated-cobalt } \\
\text { dicarbolide }\end{array}$ & $\begin{array}{l}\text { Good strontium separation. } \\
\text { Shows potential for evolving into a practical } \\
\text { process. } \\
\text { Has undergone a fair amount of development } \\
\text { (e.g., tested on actual waste). }\end{array}$ & $\begin{array}{l}\text { Due to safety concerns regarding current } \\
\text { diluents, identify and test alternative } \\
\text { diluent(s). } \\
\text { Test on simulated and actual waste to better } \\
\text { determine process robustness as related to } \\
\text { Sr separation and selectivity. } \\
\text { Look into the possibility of using this } \\
\text { system for alkaline-side strontium removal. }\end{array}$ \\
\hline \multicolumn{3}{|c|}{ Precipitation (alkaline-side strontium removal) } \\
\hline Sodium titanate & $\begin{array}{l}\text { Good strontium separation. } \\
\text { Shows potential for evolving into a practical } \\
\text { process. } \\
\text { Safe process to operate. } \\
\text { Resistance to radiation damage has been } \\
\text { indicated. } \\
\text { Has undergone a fair amount of development } \\
\text { (e.g., used on large scale). }\end{array}$ & $\begin{array}{l}\text { Conduct tests for precipitations conducted in } \\
\text { series to increase Sr separation. } \\
\text { Determine effects of complexants on } \\
\text { strontium separation. } \\
\text { Look into ultrafiltration as a means of solid } \\
\text { liquid separation. } \\
\text { Waste minimization: determine the impact } \\
\text { the precipitate will have on low-level and } \\
\text { high-level wastes. } \\
\text { Test on simulated and actual waste to better } \\
\text { determine process robustness as related to } \\
\text { Sr separation and selectivity. }\end{array}$ \\
\hline
\end{tabular}


Table S.1. (contd)

\begin{tabular}{|c|c|c|}
\hline Separation Method & Attributes Based on Available Data & Required Further Development \\
\hline \multicolumn{3}{|c|}{ Precipitation (alkaline-side strontium removal) (contd) } \\
\hline Ferric hydroxide & $\begin{array}{l}\text { Good strontium separation. } \\
\text { Shows potential for evolving into a practical } \\
\text { process. } \\
\text { Has undergone a fair amount of development } \\
\text { (e.g., tested on pilot scale, tested on actual } \\
\text { waste). }\end{array}$ & $\begin{array}{l}\text { Determine impact that precipitations con- } \\
\text { ducted in series have on Sr separation. } \\
\text { Determine effects of complexants on } \\
\text { strontium separation. } \\
\text { Determine the impact the precipitate will } \\
\text { have on low-level and high-level wastes. } \\
\text { Test on simulated and actual waste to better } \\
\text { determine process robustness as related to } \\
\text { Sr separation and selectivity. }\end{array}$ \\
\hline $\begin{array}{l}\text { Titanium hydroxide, } \\
\text { calcium carbonate, } \\
\text { manganese dioxide }\end{array}$ & $\begin{array}{l}\text { Good strontium separation. } \\
\text { Shows potential for evolving into a practical } \\
\text { process. }\end{array}$ & $\begin{array}{l}\text { Limited data are available. } \\
\text { Determine impact that precipitations } \\
\text { conducted in series have on Sr separation. } \\
\text { Determine effects of complexants on } \\
\text { strontium separation. } \\
\text { Determine the impact the precipitate will } \\
\text { have on low-level and high-level wastes. } \\
\text { Test on simulated and actual waste to better } \\
\text { determine process robustness as related to } \\
\text { Sr separation and selectivity. }\end{array}$ \\
\hline \multicolumn{3}{|c|}{ Ion Exchange (acid-side strontium removal) } \\
\hline Sr-Spec & $\begin{array}{l}\text { Good strontium separation. } \\
\text { Shows potential for evolving into a practical } \\
\text { process. } \\
\text { Has undergone a fair amount of development } \\
\text { (e.g., tested in column operation, tests } \\
\text { conducted on simulated Hanford waste). }\end{array}$ & $\begin{array}{l}\text { Test resistance to radiation damage. } \\
\text { Conduct lab-scale flow-through tests. } \\
\text { Test on simulated and actual waste to better } \\
\text { determine process robustness as related to } \\
\text { Sr separation and selectivity. }\end{array}$ \\
\hline
\end{tabular}


Table S.1. (contd)

\begin{tabular}{|c|c|c|}
\hline Separation Method & Attributes Based on Available Data & Required Further Development \\
\hline \multicolumn{3}{|c|}{ Ion Exchange (alkaline-side strontium removal) } \\
\hline Sodium titanate & $\begin{array}{l}\text { Good strontium separation. } \\
\text { Shows potential for evolving into a practical } \\
\text { process. } \\
\text { Resistant to radiation damage. } \\
\text { Has undergone a fair amount of development } \\
\text { (e.g., tested in column operation, tests } \\
\text { conducted on actual wastes). }\end{array}$ & $\begin{array}{l}\text { Conduct lab-scale flow-through tests. } \\
\text { Determine effects of complexants on } \\
\text { strontium separation. } \\
\text { Mechanical stability (e.g., alternate support } \\
\text { systems) of the sodium titanate in column } \\
\text { must be further investigated. } \\
\text { Test on simulated and actual waste to better } \\
\text { determine process robustness as related to } \\
\text { Sr separation and selectivity. }\end{array}$ \\
\hline $\begin{array}{l}\text { Silico-titanates, } \\
\text { IE-96, } \\
\text { TIE-96, } \\
\text { titanium phosphate, } \\
\text { manganese dioxide, } \\
\text { hydrous titanium oxide, } \\
\mathrm{Na}_{4} \mathrm{Mg}_{6} \mathrm{Al}_{4} \mathrm{Si}_{4} \mathrm{O}_{20} \mathrm{~F}_{4} \text { mica }\end{array}$ & Potential for good strontium separation. & $\begin{array}{l}\text { Limited or no published data in some cases. } \\
\text { Determine effects of complexants on } \\
\text { strontium separation. } \\
\text { Conduct laboratory batch and flow-through } \\
\text { tests. } \\
\text { Test on simulated and actual waste to better } \\
\text { determine process robustness as related to } \\
\text { Sr separation and selectivity. }\end{array}$ \\
\hline
\end{tabular}




\section{Nomenclature}

\begin{tabular}{|c|c|}
\hline CMPO & N,N-diisobutylcarbamoylmethylphosphine oxide \\
\hline $\mathrm{CC}$ & Complexant concentrate \\
\hline DF & Decontamination factor \\
\hline $\mathrm{D}_{\mathrm{Ba}}$ & Barium solvent extraction distribution coefficient \\
\hline $\mathrm{D}_{\mathrm{Co}_{0}}$ & Cobalt solvent extraction distribution coefficient \\
\hline $\mathrm{D}_{\mathrm{Cs}}$ & Cesium solvent extraction distribution coefficient \\
\hline $\mathrm{D}_{\mathrm{K}}$ & Potassium solvent extraction distribution coefficient \\
\hline $\mathrm{D}_{\mathbf{S}_{\mathbf{r}}}$ & Strontium solvent extraction distribution coefficient \\
\hline $\mathrm{D}_{\mathrm{Zr}}$ & Zirconium solvent extraction distribution coefficient \\
\hline EDTA & Ethylenediamine-tetra-acetic acid \\
\hline HDDNS & Didodecyl-naphthalene sulfonic acid \\
\hline HDNNS & Dinonyl-naphthalene sulfonic acid \\
\hline HDEHP & Di-(2-ethylhexyl) phosphoric acid \\
\hline HLW & High-level waste \\
\hline HWVP & Hanford Waste Vitrification Plant \\
\hline $\mathrm{Kd}$ & Ion exchange distribution coefficient \\
\hline $\mathrm{Kd}_{\mathbf{S r}_{\mathrm{r}}}$ & Strontium ion exchange distribution coefficient \\
\hline LLW & Low-level waste \\
\hline NaDEHP & Sodium-(2-ethylhexyl) phosphate \\
\hline $\mathrm{Na}_{5} \mathrm{DTPA}$ & Pentasodium di-ethylene-tri-nitrilo-penta-acetate \\
\hline $\mathrm{Na}_{4}$ EDTA & Tetrasodium ethylenediamine-tetra-acetate \\
\hline NCRW & Neutralized cladding removal waste \\
\hline PAW & Process denitrated acid waste \\
\hline PEG-400 & Polyethylene glycol compound \\
\hline PNL & Pacific Northwest Laboratory \\
\hline PUREX & Plutonium/uranium extraction process \\
\hline SNAP & Systems for Nuclear Auxiliary Power \\
\hline SREX & Strontium extraction process \\
\hline SRP & Savannah River Plant \\
\hline TBP & Tributyl phosphate \\
\hline TRU & Transuranic elements \\
\hline TRUEX & Transuranic element extraction process \\
\hline 1AW-MTR & Material Testing Reactor aqueous raffinate \\
\hline
\end{tabular}




\section{Contents}

Summary $\quad \ldots \ldots \ldots \ldots \ldots \ldots \ldots \ldots \ldots \ldots \ldots \ldots \ldots \ldots \ldots \ldots \ldots$ iii

Nomenclature $\ldots \ldots \ldots \ldots \ldots \ldots \ldots \ldots \ldots \ldots \ldots \ldots \ldots \ldots$ vii

1.0 Introduction $\ldots \ldots \ldots \ldots \ldots \ldots \ldots \ldots \ldots \ldots \ldots \ldots \ldots \ldots$

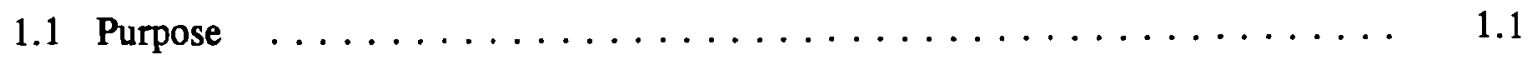

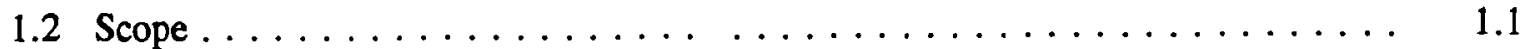

1.3 Report Contents . . . . . . . . . . . . . . . . . .

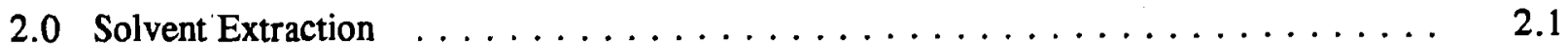

2.1 Crown Ethers $\ldots \ldots \ldots \ldots \ldots \ldots \ldots \ldots \ldots \ldots \ldots \ldots \ldots \ldots \ldots \ldots \ldots$

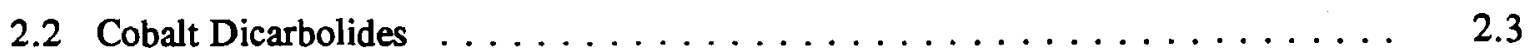

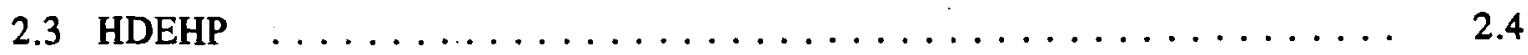

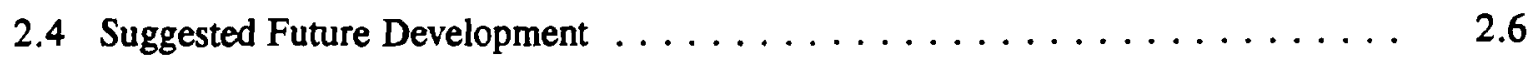

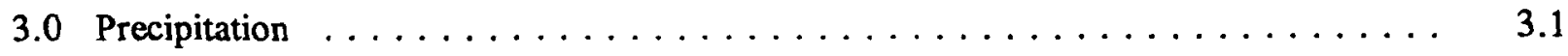

3.1 Sodium Titanate $\ldots \ldots \ldots \ldots \ldots \ldots \ldots \ldots \ldots \ldots \ldots \ldots \ldots \ldots$

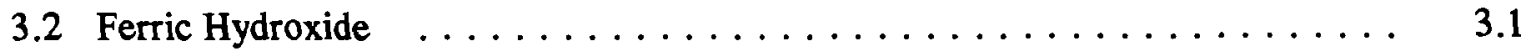

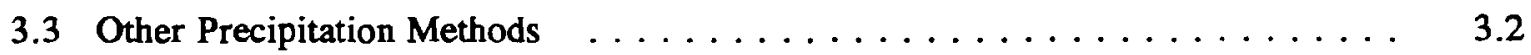

3.4 Suggested Future Development $\ldots \ldots \ldots \ldots \ldots \ldots \ldots \ldots \ldots \ldots \ldots$

4.0 Ion Exchange $\ldots \ldots \ldots \ldots \ldots \ldots \ldots \ldots \ldots \ldots \ldots \ldots \ldots \ldots \ldots$

4.1 Polyantimonic Acid $\ldots \ldots \ldots \ldots \ldots \ldots \ldots \ldots \ldots \ldots \ldots \ldots \ldots$

4.2 Sodium Titanate $\ldots \ldots \ldots \ldots \ldots \ldots \ldots \ldots \ldots \ldots \ldots \ldots \ldots \ldots$

4.3 Macrocyclic Ligands $\ldots \ldots \ldots \ldots \ldots \ldots \ldots \ldots \ldots \ldots \ldots$ 
4.4 Other Ion Exchange Methods $\ldots \ldots \ldots \ldots \ldots \ldots \ldots \ldots \ldots$

4.5 Suggested Future Development $\ldots \ldots \ldots \ldots \ldots \ldots \ldots \ldots \ldots$

5.0 Conclusions $\ldots \ldots \ldots \ldots \ldots \ldots \ldots \ldots \ldots \ldots \ldots \ldots \ldots \ldots \ldots \ldots$

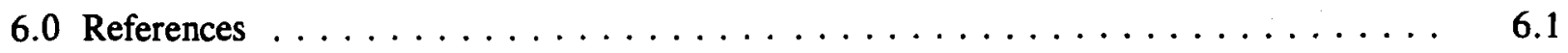

Appendix: Tabular Summary of Literature Survey $\ldots \ldots \ldots \ldots \ldots \ldots \ldots \ldots \ldots$ 


\subsection{Introduction}

Several pretreatment options are currently being considered for Hanford tank waste to separate the waste into high-level and low-level streams for final disposal. One approach would be to dissolve the

solid waste (e.g., sludge) in nitric acid and separate the transuranic (TRU) components, ${ }^{137} \mathrm{Cs}$, and ${ }^{90} \mathrm{Sr}$ from the bulk components in the dissolved sludge. The bulk components would then be disposed of as low-level waste (LLW), and the TRUs, ${ }^{137} \mathrm{Cs}$, and ${ }^{90} \mathrm{Sr}$ vitrified. This approach requires the use of separation technologies that are effective for TRU components, ${ }^{137} \mathrm{Cs}$, and ${ }^{90} \mathrm{Sr}$ in acidified as well as alkaline waste streams.

\subsection{Purpose}

This study was conducted by Pacific Northwest Laboratory (PNL) ${ }^{(a)}$ for Westinghouse Hanford Company as part of the Tank Waste Remediation System. The purpose of this report is to identify and evaluate strontium removal processes that are potentially applicable to acidified and alkaline Hanford waste streams. Cesium and TRU removal are the subjects of separate reports. Promising technologies were identified through literature searches, journal reviews, and reviews of technical society conference proceedings. Requirements for further development of the promising technologies were also identified.

\subsection{Scope}

The technologies evaluated for strontium removal included solvent extraction, precipitation, and ion exchange. Several characteristics of the waste and waste treatment were taken into account during the review and assessment of these technologies. In most cases, it is anticipated that at least $1 \underline{\mathrm{M}}$ $\mathrm{HNO}_{3}$ will be used to dissolve the sludge, although significant dissolution may occur at $\mathrm{pH}<2.0$. Thus, for this investigation, acidified waste was defined as having a $\mathrm{pH}<2.0$. Alkaline waste was defined as having a $\mathrm{pH}>10.0$.

Although required decontamination factor (DF) values for strontium are not known for each Hanford waste tank, average values are available. In a recent report (Straalsund et al. 1992) it was noted that, based on an overall average composition of the single-shell tank waste and $5 \underline{M}$ sodium to LLW, a minimum strontium DF of $2.5 \times 10^{3}$ would be required so that the bulk components could be disposed of as low-level Class A waste (10 CFR 61). It should be noted that these reported strontium DFs were for the total waste (supernatant + solids) prior to acid dissolution. Compiled tank waste data indicate that as much as $96 \%$ of the total strontium is present in the solids. Taking this into account, and by

(a) Operated for the U.S. Department of Energy by Battelle Memorial Institute under Contract DE-AC06-76RLO 1830. 
assuming that equal amounts of strontium are to be left in the treated solid and liquid portions, minimum DFs of $5 \times 10^{3}$ for acid-side (solids) processing and 200 for alkaline-side (supernatant) processing would be required. Due to the sum-of-fractions-rule and variations in waste composition, it is recommended that target DFs be approximately tenfold higher than the minimum DF values. Thus, strontium DFs of approximately $5 \times 10^{4}$ for acid-side processing, and $2 \times 10^{3}$ for alkaline-side processing of single-shell tanks can be calculated. These calculated DFs were used as guidelines to assess the various strontium separation technologies presented in this report.

Much of the strontium present in the supernatant could be complexed with chelating agents such as EDTA. This could have significant effects on processing and required DFs for alkaline-side processing. Chelated-strontium complexes may be more difficult to separate than noncomplexed strontium. Thus, the impact of complexants for given alkaline-side strontium separation methods must be evaluated. In cases where the presence of complexants is detrimental to strontium separation, pretreatment steps could be included to destroy the organic chelating agent(s). When the chelating agent is destroyed, additional strontium may precipitate from solution. Thus, destruction of the chelating agent, in itself, may be a potential method for separating strontium from alkaline waste.

The presence of bulk components such as sodium, iron, zirconium, zinc, and bismuth was considered when reviewing the literature and evaluating the technologies for the separation of strontium. Safety and health issues, process simplicity, as well as the impact of the product streams on the vitrification plant and waste form, were also considered in evaluating the technologies.

\subsection{Report Contents}

Sections 2.0 through 4.0 discuss separation of strontium by solvent extraction, precipitation, and ion exchange, respectively. For each separation technology, the discussion includes the pertinent literature relating to specific potentially viable systems. Furthermore, the advantages and limitations of each system are explored. Further development issues are then put forth.

Section 5.0 provides the overall conclusions drawn from this study. The appendix tabulates the results of the literature survey, and provides the experimental conditions used for the separation methods that were evaluated.

Information sources for this review included Energy Research Abstracts, Nuclear Science Abstracts, and Chemical Abstracts, as well as consultation with experts in the field. Recent review articles have also addressed some of the studies that are discussed below (Schulz and Bray 1987; Reilley, Mason, and Smith 1990; Kolarik 1991; Gerber 1992). 


\subsection{Solvent Extraction}

A review of the literature has revealed that two solvent extraction systems currently show promise in separating strontium from waste streams. In one case, crown ethers are used as the primary extractants, while in the other case cobalt dicarbolides are the primary extractants. Both of these systems operate in acidic media. In the past, di-(2-ethylhexyl) phosphoric acid (HDEHP) also has been used to separate strontium from waste; however, the addition of complexants in this process makes it less attractive than the other two solvent extraction systems. The studies discussed below are summarized in Tables A.1 through A.3 in the appendix.

\subsection{Crown Ethers}

The studies on crown ethers described here have focused on using various solvents, additives, and crown ethers to increase the extraction of strontium from mainly acidified waste streams. The early studies (Gerow and Davis 1979; Gerow, Smith, and Davis 1981) focused on the use of organic soluble anions + crown ethers to promote the extraction of strontium into the organic phase. In both investigations, kerosene + tributyl phosphate (TBP) was also present in the organic phase. Gerow and Davis (1979) used HDEHP as the organic ion exchanger, and very high $\mathrm{D}_{\mathrm{Sr}}$ (strontium distribution coefficient) values were obtained. The highest $\mathrm{pH}$ tested in these studies was 5.5; however, the extraction of strontium remained high and constant from $\mathrm{pH}=3.5$ to 5.5 , indicating that at higher $\mathrm{pHs}$ the extraction of strontium may also be high. Shakeout tests at higher pHs should be conducted to determine whether this is the case. It was observed that the presence of HDEHP in solution significantly enhanced the extraction of strontium. Efficient stripping of strontium was observed at $\mathrm{pH}<0.2$ for this system.

Gerow, Smith, and Davis (1981) used didodecyl-naphthalene sulfonic acid (HDDNS) as the organic ion exchanger. They evaluated numerous crown ethers and observed that, of those crown ethers tested, strontium was extracted to approximately the same extent. They also observed that the presence of crown ether had little effect on the extraction of strontium. The presence of HDDNS was the most important factor for the extraction of strontium. The strontium was efficiently stripped from the organic phase by $1 \underline{\mathrm{M}} \mathrm{HNO}_{3}$.

These two early studies showed that the presence of an organic ion exchanger was essential for extracting strontium into a crown ether-kerosene-TBP system. Also, although in both studies the highest $\mathrm{pH}$ investigated was 5.5, the trend in the data indicated that high $\mathrm{D}_{\mathrm{Sr}}$ values may be achieved at higher pHs. Finally, the presence of crown ethers may not even be required in this system to achieve adequate extraction of strontium. No data were presented in these studies on the coextraction of other metals (e.g., zirconium, iron, etc.).

In another study (Shuler et al. 1985) in which a crown ether-dinonyl-naphthalene sulfonic acid (HDNNS)-TBP-kerosene extraction system was used, coextraction of other metals such as zirconium and barium was observed. The extraction of zirconium was attributed to the presence of TBP. These 
studies were conducted at $3 \underline{\mathrm{M}} \mathrm{HNO}_{3}$. The authors observed that the crown ether concentration had a significant impact on the extraction of strontium at this high acid concentration. $\mathrm{A} \mathrm{D}_{\mathrm{Sr}}$ of 6.4 was achieved at $0.1 \underline{\mathrm{M}}$ crown ether concentration; however a third phase formed, even though the solubility limit had not been exceeded.

Other studies have focused on using alternative diluents to enhance the extraction of strontium by crown ethers. Blausius, Klein, and Schon (1985) tested various diluents and found that crown ether dissolved in 1,1,2 tetrachloroethane gave promising strontium extraction results. Similar results were obtained by Myasoedova et al. (1987) when crown ether was dissolved in tetrachloroethane. In that study, extraction from $3 \underline{\mathrm{M}} \mathrm{HNO}_{3}$ was tested; in the 1985 study, extraction from $1 \underline{\mathrm{M}} \mathrm{HNO}_{3}$ was tested. In both studies, chlorinated hydrocarbons were used as the diluent. The use of these types of diluents is not desirable due to their toxicities and due to the generation of corrosive hydrochloric acid upon radiolytic degradation. If these diluents were to be considered, comprehensive radiolytic degradation studies would be required to determine whether toxicity and/or corrosion would be a concern when processing the actual waste.

McDowell et al. (1986) tested crown ethers in HDDNS + toluene. Nitric acid concentrations between 0.1 and $0.5 \underline{\mathrm{M}}$ were tested. Very favorable strontium extraction was achieved. However, toluene is not a practical diluent because it has a low flash point (i.e., $4.4^{\circ} \mathrm{C}$ ).

More recently, a variety of alcohols, ketones, and carboxylic acids were investigated as potential diluents for crown ether extraction systems (Horwitz, Dietz, and Fisher 1990a). In this study, alcohols and ketones were found to be most effective as diluents. It was also observed that as the number of carbons decreased, the extraction of strontium increased. However, from a practical standpoint, there is a lower limit on the size of an alcohol or ketone (i.e., due to flashpoint, aqueous phase solubility, etc.).

In a follow-up study, Horwitz, Dietz, and Fisher (1990b) tested a variety of diluents and concluded that octanol was the preferred diluent when considering such characteristics as the ability to extract strontium, the flash point, and the density. Also, various crown ethers were investigated, and $4,4^{\prime}\left(5^{\prime}\right)$ di-tertiary-butyl-dicyclohexyl-18-C-6 showed the most promise when considering strontium extraction and the solubility in the aqueous phase. It was found that good strontium extraction could be achieved in $3 \underline{\mathrm{M}} \mathrm{HNO}_{3}$, while the strontium could be efficiently stripped in $0.05 \underline{\mathrm{M}} \mathrm{HNO}_{3}$.

In another study (Horwitz, Dietz, and Fisher 1991a), tests were conducted using the octanol-crown ether system to extract strontium from synthetic waste. The synthetic waste was formulated to duplicate the expected composition resulting from the dissolution of Hanford waste sludges. In addition to strontium, only barium had a distribution coefficient greater than 1.0 in $3 \underline{\mathrm{M}} \mathrm{HNO}_{3}$. Strontium selectivity over other metals increased with increasing $\mathrm{HNO}_{3}$ concentration; the only exception was that the selectivity of strontium over calcium remained constant over the $\mathrm{HNO}_{3}$ concentrations investigated. The system showed good hydrolytic stability, and only showed adverse effects when exposed to dose rates much higher than those anticipated in treating the waste. A 3-stage extraction, 6-stage scrub, and 5-stage strip countercurrent flowsheet was tested in the laboratory. Approximately 
99.7\% of the strontium that entered in the feed was removed in this test (i.e., strontium decontamination factor, $\mathrm{DF}_{\mathrm{Sr}_{\mathrm{r}}}=333$ ). The strontium extraction varied appreciably from one lot of the same crown ether to the next in this study. The authors suggested this variation may be caused, in part, by the variation in the different crown ether isomers from one lot to the next.

Lumetta et al. (1991) tested the octanol-4,4'(5')di-tertiary-butyl-dicyclohexyl-18-C-6 system for the removal of strontium from acidified synthetic Hanford complexant concentrate (CC) waste. In this study, three consecutive contacts, having organic/aqueous ratios of 0.33 , were made in $1.1 \underline{\mathrm{M}} \mathrm{HNO}_{3}$. An overall strontium DF of 40 was achieved. Higher acid concentrations and organic/aqueous ratios would increase the extraction of strontium.

Horwitz (1991) proposed combining processes for transuranic element extraction (TRUEX) and strontium extraction (SREX). The combined solvent extraction system consisted of $\mathrm{N}, \mathrm{N}$ diisobutylcarbamoylmethylphosphine oxide (CMPO) to extract TRUs, and 4,4'(5')di-tertiary-butyldicyclohexyl-18-C-6 to extract strontium and TBP in Isopar-L. The extraction of strontium was unaffected by the presence of CMPO, and the extraction of TRUs was unaffected by the presence of the crown ether. In both cases, favorable distribution coefficients were obtained, although the strontium distribution factor was not as high as that obtained in the crown ether-octanol extraction system (Horwitz, Dietz, and Fisher 1990b, 1991a).

Filipov et al. (1992) reported that $97.5 \%$ of the strontium from high-level radioactive waste was extracted and recovered in pilot studies. Dicyclohexyl-18-crown-6 in a proprietary diluent was used in this study. The solvent extraction system consisted of 9 extraction, 2 scrub, and 6 strip stages. It was noted that the crown ether concentration in the raffinate reached $300 \mathrm{mg} / \mathrm{L}$.

\subsection{Cobalt Dicarbolides}

Investigations into the use of cobalt dicarbolide as an extractant for the separation of strontium as well as cesium have been primarily conducted by Czech and Russian scientists. In the studies, very favorable $\mathrm{D}_{\mathrm{Sr}}$ values were obtained for $\mathrm{HNO}_{3}$ concentrations ranging from $0 \underline{\mathrm{M}}$ to $1.0 \underline{\mathrm{M}}$. However, to achieve these high strontium extraction values, nitrobenzene had to be used as the solvent. The high degree of cobalt dicarbolide solubility in nitrobenzene is a major reason nitrobenzene serves as such a good solvent (Rais et al. 1976). One interesting item was that the solubility of cobalt dicarbolide in TBP was comparable to that in nitrobenzene. However, there was only limited cesium and no strontium distribution data. The limited cesium distribution data indicated that cesium did not extract as well into the TBP system. It may be useful to conduct additional tests, using TBP as the solvent.

For the most part, the successful extraction of strontium has been achieved by using a chlorinated derivative of cobalt dicarbolide or adding a polyethylene glycol (PEG) to the cobalt dicarbolide system (Reilly, Mason, and Smith 1990; Kolarik 1991). It has also been noted in the literature that cesium extraction is essentially the same for cobalt dicarbolide or the chlorinated cobalt dicarbolide derivative 
(Koprda and Scasnar 1979; Scasnar and Koprda 1980). Thus, if a chlorinated cobalt dicarbolide derivative were used, simultaneous extraction of cesium and strontium may be possible.

Rais et al. (1976) found that the addition of $0.2 \underline{\mathrm{M}}$ of PEG compound (PEG-400) increased the extraction of strontium by $1000 \mathrm{X}$. Also, for the experimental conditions studied, $0.2 \underline{\mathrm{M}} \mathrm{PEG}-400$ gave the best strontium extraction. Higher molecular weight PEGs were also tested. The strontium extrac-

tion decreased as the molecular weight of the PEG increased. With respect to selectivity, $\mathrm{Ba}^{2+}$ was the only alkaline earth metal that had a higher DF than strontium. In a later study conducted by Koprda, Scasnar, and Galan (1983), comparable strontium DFs were obtained under similar experimental conditions.

Another study, which focused on the analytical determination of strontium, used a complexing agent along with PEG-400 (Selucky et al. 1979). The complexing agent, pentasodium di-ethylene-trinitrilo-penta-acetate ( $\left.\mathrm{Na}_{5} \mathrm{DTPA}\right)$, was used to inhibit strontium, zirconium, and lanthanides extraction at $\mathrm{pH}>8.5$, and to inhibit zirconium and lanthanides extraction at $\mathrm{pH}<4.0$. At $\mathrm{pH}>8.5$, cesium was extracted, and, when the $\mathrm{pH}$ was adjusted to 4.0, strontium was extracted.

The extraction of strontium in the absence of a PEG compound was reported in an article that was mainly concerned with the extraction of cesium by cobalt dicarbolide (Scasnar and Koprda 1980). In this study it was observed that strontium was effectively extracted when no $\mathrm{HNO}_{3}$ was present. In the absence of $\mathrm{HNO}_{3}$, cesium and strontium distribution coefficients were comparable to one another, followed by potassium that had a distribution coefficient of 24 . Sodium and cobalt were other metals that had distribution coefficients greater than 1.0. At a $0.01 \underline{\mathrm{M}} \mathrm{HNO}_{3}$ concentration, $\mathrm{D}_{\mathrm{Sr}}$ decreased to 8.95, and at a $0.1 \underline{\mathrm{M}} \mathrm{HNO}_{3}$ concentration, $\mathrm{D}_{\mathrm{Sr}_{\mathrm{r}}}=0.085$. For comparison, Koprda and Scasnar (1983) conducted a later study under similar experimental conditions (i.e., $0.1 \underline{\mathrm{M}} \mathrm{HNO}_{3}$ ) except that $0.1 \mathrm{wt} \%$ PEG was added. In that study, a $D_{S r}$ of 600 was obtained.

A recent review article (Reilly, Mason, and Smith 1991) mentioned that p-nonyl-phenyl-nonaethylene-glycol (Slovafol 909) has been used in the place of PEG, because Slovafol 909 is less soluble in the aqueous phase. This same review article presented strontium extraction data using a chlorinated cobalt dicarbolide derivative for the extraction of strontium. It was noted that $>95 \%$ strontium was extracted; however, the exact test conditions were not given. In another study (Esimantovskii et al. 1992), the use of the chlorinated cobalt dicarbolide was tested, and it appeared that approximately $98 \%$ of the strontium was extracted. However, the exact conditions of the test were not presented.

\subsection{HDEHP}

An HDEHP extraction process was first investigated by Horner et al. (1963) for strontium removal from waste streams. The process was then modified and used at Hanford B-plant for several years to purify ${ }^{90} \mathrm{Sr}$ from acidified process sludge from the plutonium/uranium extraction (PUREX) plant. In the HDEHP process, various complexants were used to prevent the coextraction of iron, aluminum, and other bulk components. These reagents also complexed with americium and plutonium. These 
reagents, along with the complexed species, exited the solvent extraction circuit in the raffinate stream. Throughout the processing time, approximately 4 million gallons of waste containing these complexing agents were generated. This waste is currently stored in tanks and will require treatment to remove the transuranic species and to destroy the organic complexants.

A three-cycle HDEHP extraction flowsheet was proposed and tested in the laboratory for the extraction of strontium from evaporation-concentrated raffinate from the PUREX process. In the first cycle, strontium and lanthanides were coextracted and costripped; in the second cycle the pH was adjusted such that only lanthanides were extracted; and in the third cycle, the strontium was concentrated and further separated from sodium and radioactive contaminants. In the feed to the first cycle, $\mathrm{NaOH}$ was added to increase the $\mathrm{pH}$ to $4.5-6$, and sodium tartrate was added to prevent iron from precipitating. The lanthanides and strontium were stripped in all cycles by adding $1.5-2 \underline{\mathrm{M} \mathrm{HNO}}$. The lanthanides were preferentially extracted away from strontium in the second cycle by adjusting the feed to a $\mathrm{pH}$ of 2 . The feed to the third cycle was adjusted to a $\mathrm{pH}$ of $4.5-6$ by adding $\mathrm{NaOH}$, and again sodium tartrate was added to prevent iron from precipitating. The strontium product contained an approximately equivalent amount of nickel; however, the addition of a small amount of ethylenediamine-tetra-acetic acid (EDTA) to the third cycle feed prevented the extraction of nickel. Overall, approximately $99.7 \%$ of the strontium entering the extraction circuit was recovered in the product stream. Related development work has been described elsewhere (Wischow and Horner 1962).

Schulz, Mendel, and Richardson (1963) described some laboratory work that was done to form a basis for the chemical flowsheets used in the Hanford Hot Semiworks plant. This process was used to produce approximately 1 megacurie of purified ${ }^{90} \mathrm{Sr}$ for the fabrication of thermoelectric power generators as part of the Systems for Nuclear Auxiliary Power (SNAP) program. The feed to the process was Hanford PUREX plant crude ${ }^{90} \mathrm{Sr}$ concentrate solution. In the process, the feed $\mathrm{pH}$ was maintained at 4.7. Sodium hydroxide was added to the feed to increase the $\mathrm{pH}$, and acetic acid and sodium acetate were used as buffering agents to maintain the $\mathrm{pH}$ at 4.7. Tetrasodium ethylenediamine-tetra-acetate ( $\mathrm{Na}_{4}$ EDTA) or $\mathrm{Na}_{5}$ DTPA was added to the feed to suppress the extraction of iron, lead, and some fission products. A citrate solution was used to scrub the extracted sodium from the organic phase. The strontium was then stripped by using $1 \mathrm{M}$ citric acid. This also provided for partial decontamination from coextracted calcium and lanthanide fission products. In countercurrent runs, using mixersettlers, $95 \%$ of the strontium was recovered in the product with calcium being the major contaminant. The countercurrent system consisted of 7 extraction, 5 scrub, and 5 strip stages. The $\mathrm{D}_{\mathrm{Sr}}$ is for one batch contact under extraction section conditions. The actual hot processing of strontium in the Hot Semiworks pilot plant at Hanford was initiated in May 1961 and was completed in October 1961. These production runs, along with aspects of the process development, have been summarized by Hill (1963).

Schulz (1964) and Richardson (1964) conducted laboratory and pilot-scale tests, respectively, for the separation of strontium and lanthanides from PUREX process denitrated acid waste (PAW) solution. The main features of the process were that the feed to the extraction column was adjusted to a $\mathrm{pH}$ of 4 to 5 by adding $\mathrm{NaOH}$. Citric acid was also added to the feed to prevent the extraction of inert and radioactive constituents with the exception of sodium and calcium. Dilute citric acid (Schulz 1964) or 
formic acid (Richardson 1964) was then used in the scrub section to remove extracted sodium from the organic phase. Strontium was stripped from the organic by contacting the organic with dilute $\mathrm{HNO}_{3}$ (i.e., $\mathrm{pH}=1.5-2$ ). The lanthanides were then stripped by contacting the organic with $0.5-2 \underline{\mathrm{M}} \mathrm{HNO}_{3}$. The organic phase was washed at elevated temperature with an alkaline solution to remove iron, aluminum, chromium, zirconium, yttrium, etc. In the laboratory studies, batch as well as countercurrent continuous tests were made using mixer-settlers. In the pilot runs, 3-in. pulsed columns were used. The extraction was conducted at $50^{\circ} \mathrm{C}$ so that cerium could be more efficiently extracted. Over $99 \%$ of the strontium and $90 \%$ of the lanthanides were recovered in the product streams from this process.

\subsection{Suggested Future Development}

Overall, the crown ether systems, particularly the one described by Horwitz, Dietz, and Fisher (1990a,b; 1991a), appear to be the most viable at this time. The need to use complexants in the HDEHP process to suppress the extraction of other bulk elements makes it less desirable than either the crown ether or cobalt dicarbolide systems. In general, the strontium distribution coefficients obtained in the cobalt dicarbolide system were larger than those obtained in the crown ether system. However, the use of nitrobenzene as a diluent is not attractive.

The following recommendations are given in a stepwise order that leads from one stage of development to the next.

- Identify alternative practical diluents for the cobalt dicarbolide system.

The key to making the process practical is to identify diluents that can be safely used in the extraction processes while maintaining the high strontium extraction and selectivity.

In one article, it was suggested that the solubility of the cobalt dicarbolide in the solvent is an important factor in achieving good metal extraction (Rais, Selucky, and Kyrs 1976). In this same article, it was noted that the solubility of cobalt dicarbolide in TBP was comparable to that in nitrobenzene. As suggested previously, it may be useful to conduct additional tests using TBP as the solvent. Also, the addition of HDDNS or HDNNS may have an impact in this type of a system, as in the crown ether system.

- Look into the coextraction of cesium and strontium in the chlorinated cobalt dicarbolide system.

- Investigate the degree of strontium extraction from alkaline feed streams for the cobalt dicarbolide and crown ether solvent extraction systems.

Most of the extraction data to date have focused on acidic streams; however, some data have indicated that extraction from alkaline solutions may also be possible. 
- Investigate the degree of extraction of other elements for the cobalt dicarbolide and crown ether solvent extraction systems.

While the capability to extract strontium is important, equally important is the separation of strontium from the bulk components of the waste. Thus, additional laboratory data on the extraction of such elements as sodium, iron, zirconium, zinc, calcium, bismuth, strontium should be obtained under various conditions (e.g., pH). This will aid in determining the number of scrub stages required and the required scrub solutions.

- Investigate the stripping capabilities of the cobalt dicarbolide and the crown ether systems.

Most of the studies thus far have keyed in on the extraction aspects of the strontium, and have not dealt in detail with the ability to strip strontium from the organic phase once it is loaded.

- Investigate the degree of chemical and radiolytic degradation for the cobalt dicarbolide (especially the chlorinated dicarbolide) and crown ether systems.

It has been suggested in the literature that both the crown ether and dicarbolide systems are attractive due to the resistance to radiolytic degradation; however, limited data are available. Radiolytic or chemical breakdown of the chlorinated cobalt dicarbolide complex could lead to increased corrosion due to the chloride. Also, chemical degradation due to the extraction and inability to strip certain components may cause problems in the overall process.

- Develop a flowsheet using batch testing of actual waste for the cobalt dicarbolide and crown ether systems.

To date, most of the tests have been conducted using simulated wastes prepared in the laboratory. Thus, batch laboratory tests will be required to evaluate the extraction performance for actual waste. This should be done to develop a solvent extraction flowsheet for each waste type of interest.

- Conduct countercurrent contacting tests using simulated and actual wastes.

Bench-scale countercurrent testing will be required to confirm and further develop the process chemistry flowsheets for use on pilot- and large-scale systems. 


\subsection{Precipitation}

Several precipitation methods have potential for separating strontium from alkaline waste streams. Lead sulfate was the only acid-side strontium precipitation method identified. Several limitations prevent this method from being viable. The studies discussed below are summarized in Tables A.4 through A. 6 in the appendix.

\subsection{Sodium Titanate}

Lee and Kilpatrick (1982) studied the use of a precipitation/adsorption process to remove cesium, strontium, and plutonium from Savannah River alkaline waste. In their study, a slurry of tetraphenylborate and sodium titanate was added to the waste. The tetraphenylborate precipitated the cesium from solution (cesium DF $=10^{5}$ to $10^{6}$ ), and the strontium and plutonium were adsorbed onto the solid sodium titanate (i.e., strontium $D F=200$ to 300 , plutonium $D F=100$ to 400 ). The resulting solids were removed from solution via cross-flow filtration. Using sodium titanate as a precipitant rather than in an ion exchange column is preferable in this case because it can be combined with the sodium tetraphenylborate to remove cesium, strontium, and plutonium in one step.

Following the study, over 500,000 gal of actual Savannah River alkaline supernatant waste were processed in a demonstration test, using sodium tetraphenylborate to precipitate cesium and sodium titanate to remove strontium and plutonium (Martin et al. 1984). Again, a cross-flow filter was used to separate the supernatant from the precipitate. A minimum 2-day contact time was required to maximize the amount of strontium that was precipitated. An overall strontium DF of at least 200 was achieved in the demonstration test.

Bray et al. (1984) investigated the use of sodium titanate for the precipitation of strontium and plutonium from West Valley alkaline supernatant. The effects of parameters such as mole ratio of sodium titanate/strontium, $\mathrm{pH}$, contact time, and temperature were evaluated. It was also observed that a minimum contact time of 2 days was required. Temperature had little or no effect on strontium removal (i.e., precipitations at $25^{\circ} \mathrm{C}$ and $50^{\circ} \mathrm{C}$ were conducted). The recovery of strontium decreased by a factor of 10 when the solution $\mathrm{pH}$ was decreased from 13.7 to 10.4 .

\subsection{Ferric Hydroxide}

The use of ferric hydroxide precipitation to remove strontium and plutonium has been investigated as an option in treating aged liquid wastes produced at Saluggia (Pietrelli, Grossi, and Troiani 1988; Pietrelli and Troiani 1990; Grossi et al. 1992a,b). Three alternative processes for removing cesium, strontium, and plutonium have been considered. Two of the processes involved using sodium hydroxide to raise the $\mathrm{pH}$ of the waste to $>13$, and coprecipitating the strontium and plutonium with the iron hydroxide, then using either ion exchange or precipitation to remove the cesium. The iron was 
originally present in the acidic waste, and thus did not have to be added. The other process, which appears to have been dropped from consideration, was an acid-side process in which cesium was removed by precipitation with phosphotungstic acid, and strontium and plutonium were removed by adsorption of polyantimonic acid.

It has been reported that the ferric hydroxide removal process takes place rapidly, and that increasing the contact time from $30 \mathrm{~min}$ to $2 \mathrm{hr}$ had no measurable impact on strontium or plutonium removal (Pietrelli, Grossi, and Troiani 1988; Pietrelli and Troiani 1990). For tests in which the strontium-ironprecipitant remained in solution for 13 days, insignificant amounts of strontium redissolved in solution (Pietrelli and Troiani 1990).

The results of cold pilot runs using the two alkaline processes described above were reported recently by Grossi et al. (1992a,b). They concluded that either of the alkaline routes gave adequate separation of strontium (i.e., $\mathrm{DF}_{\mathrm{Sr}_{\mathrm{r}}}>100$ ) as well as cesium and plutonium to reach their goals.

It is unclear from these reported results whether the $\mathrm{pH}$ adjustment from 10 to 13 is actually causing the strontium to precipitate from solution or whether the ferric hydroxide precipitation is allowing strontium to precipitate. It is likely, however, that the $\mathrm{pH}$ adjustment allows strontium to precipitate, and the precipitated ferric hydroxide acts to "carry" the precipitated strontium out of solution, providing a bulkier precipitate for better solid/liquid separation.

\subsection{Other Precipitation Methods}

The use of lead sulfate for the precipitation of strontium at the Hanford Site has been documented (Bray and Van Tuyl 1961; Richardson 1965). These studies were conducted to develop a method for precipitating strontium from PUREX waste. The method, followed by ion exchange using DOWEX-50 (Bray et al. 1961), was later implemented for the recovery of approximately a megacurie of purified ${ }^{90} \mathrm{Sr}$. In the laboratory studies (Bray and Van Tuyl 1961) and pilot studies (Richardson 1965) it was noted that over $95 \%$ of the strontium was recovered by precipitation at $80^{\circ} \mathrm{C}$ and at $\mathrm{pH}$ values between 0.4 and 4.0. The sulfate concentrations ranged from 0.67 to $3 \underline{\mathrm{M}}$, and $0.02 \mathrm{M}$ lead carrier was added. Metathesis of the precipitate with carbonate-hydroxide mixtures removed the lead and converted the precipitate to an acid soluble form while minimizing strontium losses. The strontium was separated from the lanthanides by dissolution in nitric acid, followed by oxalate precipitation.

The general procedures described above were used on a large scale to recover strontium from PUREX waste as a strontium crude product which was further processed by ion exchange (DOWEX-50) (Bray et al. 1961). In these runs, an overall strontium yield of approximately 55\% was achieved. These relatively low strontium yields, along with the numerous chemical addition steps and the toxicity of lead, preclude this method from consideration for the decontamination of strontium from tank wastes. 
Other methods have been used in different studies. Studies were conducted using titanium hydroxide to precipitate strontium from pond waters (Gutman et al. 1986). The use of ultrafiltration, with the addition of titanium hydroxide, was fairly successful in achieving high strontium DFs. As compared with settling or centrifugal techniques for separating the precipitated solids, ultrafiltration was shown to be far superior. For example, to achieve a strontium DF $>100$ in the pond water treatment, 4 ppm titanium hydroxide were required when ultrafiltration was used, as compared with $600 \mathrm{ppm}$ titanium hydroxide when settling or centrifugal separation was used.

The same study evaluated the use of a calcium phosphate precipitation method to remove strontium from contaminated pond water. Compared with the titanium hydroxide precipitation method, the addition of much more calcium phosphate was required to achieve a similar strontium DF. In addition, the calcium phosphate method was very sensitive to $\mathrm{pH}$, for example at $\mathrm{pH}=9.5$, under otherwise the same conditions. A strontium DF of $<2$ was obtained. Again, ultrafiltration showed improvement over gravity or centrifugal separation in achieving high strontium DFs. It was noted elsewhere that strontium DFs $>100$ could be achieved by using calcium (or iron) phosphate at $\mathrm{pH}=11$ (CarleyMacauly et al. 1981). Carley-Macauly et al. (1981) also noted that calcium carbonate, barium sulfate, and manganese dioxide were effective precipitation methods for removing strontium from alkaline waste streams.

\subsection{Suggested Future Development}

Only lead sulfate was identified as a potential precipitation method for removing strontium from acid waste. However, the effectiveness of this method is limited by relatively low strontium yields, numerous chemical additions, and the toxicity of lead.

Several precipitation methods showed promise for removing strontium from alkaline waste: sodium titanate, ferric hydroxide, titanium hydroxide, calcium carbonate, manganese dioxide, and barium sulfate. The keys are how much of each is required to obtain sufficient strontium DFs and how specific they are to strontium. Barium sulfate is probably not desirable due to the sulfate limit that is placed on the feed to the Hanford Waste Vitrification Plant (HWVP). Also the use of ultrafiltration appears to be instrumental in decreasing the amount of carrier precipitate that is required.

The following future development is suggested to effectively evaluate the precipitation processes for the removal of strontium from alkaline waste.

- Conduct laboratory testing on strontium-containing solutions.

This should be done to determine and compare DF values for strontium by the different precipitation methods. Precipitant volume and the effects of $\mathrm{pH}$, temperature, mixing time, precipitate particle size, and precipitate settling and filterability should be investigated. 
- Conduct laboratory studies comparing ultrafiltration, centrifugal separation, and gravity separation.

It was demonstrated that ultrafiltration can lead to the use of smaller amounts of carrier precipitates (especially for fine precipitates) to achieve given strontium DFs. This leads to less waste generation.

- Conduct laboratory studies on strontium-containing solutions, using precipitations conducted in series.

Successive precipitations may increase the strontium DF dramatically. In this testing, the supernatant from the first precipitation would be treated with the carrier precipitant, again in a second precipitation step.

- For alkaline-side processing, conduct studies to determine the effects that complexants (e.g., EDTA) have on strontium separation.

- The precipitation of other elements (e.g., sodium, iron, zinc, zirconium, calcium, bismuth) from the waste should be evaluated, so that separation factors can be determined.

- Conduct laboratory studies using simulated waste.

- Evaluate the impact that the generated precipitate product will have on the glass plant, and evaluate the impact that the resulting supernatant product will have on the LLW.

- Investigate the degree of chemical and radiolytic degradation for the precipitation process(es).

- Develop flowsheets using laboratory test results as applied to actual waste for the precipitation process(es).

- Conduct larger-scale filtering tests for the precipitation process(es). 


\subsection{Ion Exchange}

Several ion exchange materials may be suitable to separate strontium from acidified and alkaline waste streams. The studies discussed below are summarized in Tables A.7 through A.10 in the appendix.

\subsection{Polyantimonic Acid}

Baetsle et al. (1965) conducted studies for the separation of ${ }^{90} \mathrm{Sr}$ from an acidic medium, using polyantimonic acid as the ion exchange material. They found that relatively large strontium DFs could be attained, but the kinetics were extremely slow. The addition of such compounds as $\mathrm{Na}_{2} \mathrm{SiO}_{3}$ increased the kinetics somewhat, but not enough to make the ion exchange process practical. In a later study (Baetsle, Huys, and Speeckaert 1973), polyantimonic acid was again investigated for the separation of strontium from fission product waste. Again, the kinetics were found to be slow. Elution was possible with $\mathrm{AgNO}_{3}$ or $\mathrm{Pb}\left(\mathrm{NO}_{3}\right)_{2}$; however, after this treatment, all adsorption capacity for strontium was lost. As an alternative, volatilization of the inert ion exchange material from the strontium product was attempted. The vast differences in the volatilities between $\mathrm{SbCl}_{5}$ and $\mathrm{SrCl}_{2}$ were taken into account to accomplish this separation. It was found, however, that the more stable $\mathrm{SbCl}_{3}$ complex was formed in many instances, making this separation more difficult (i.e., higher temperatures were required to volatilize the $\mathrm{SbCl}_{3}$ ).

The use of polyantimonic acid to recover strontium from HLW was investigated at Hanford (Davis, Partridge, and Koski 1977). In this study, precipitation, solvent extraction, and ion exchange processes were reviewed, and process concepts were prepared for the recovery of strontium from $1 \underline{\mathrm{M}} \mathrm{HNO}_{3}$ waste. Other processes such as lead sulfate precipitation, HDEHP solvent extraction, and DOWEX-50W, X-12 were also considered for recovery of strontium. Mainly due to the generation of excess waste, these processes were dropped from consideration in this study. Polyantimonic acid was determined to be the preferred technology for the recovery of strontium from $1 \underline{\mathrm{M}} \mathrm{HNO}_{3}$ waste streams. However, the slow kinetics and the difficulties involved in eluting the strontium from the exchanger were noted as being severe limitations. In the study it was noted that "additional work in the area of strontium recovery from acid solution is needed to find an adsorbent with better kinetics."

McKee et al. (1983) conducted column testing of polyantimonic acid for the removal of strontium from simulated HLW. In these studies it was observed that strontium breakthrough was extremely sensitive to flow rate through the column, indicating again that kinetics plays a role in the effectiveness of this system for removing strontium from solution.

Pietrelli et al. (1986) investigated the use of polyantimonic acid for the removal of strontium from 1AW-MTR (Material Testing Reactor aqueous raffinate) wastes (i.e., $1.1 \underline{\mathrm{M}} \mathrm{HNO}_{3}$ ). Two flowsheets were proposed: the first used polyantimonic acid to remove strontium and actinides, and, in the second, the waste stream was adjusted to a $\mathrm{pH}$ of $>13$ by the addition of $\mathrm{NaOH}$, and the strontium and 
actinides were removed by coprecipitation with ferric hydroxide. Preliminary batch tests revealed that fairly good distribution coefficients and exchange capacities for polyantimonic acid were obtained. Batch tests using zirconium phosphate, ammonium phosphomolybdate, and a mixture of ammonium phosphotungstate and zirconium phosphate were also conducted. These ion exchangers showed varying degrees of affinity for cesium, but no affinity for strontium was observed. In a later publication (Grossi et al. 1992) it was noted that the alkaline-side process appeared to be the best "reference process" because, with respect to both cesium and strontium separation, large DFs were obtained; the process was simple; process chemicals were readily available; and the processing steps (e.g., ferric hydroxide coprecipitation of strontium) had proven satisfactory in hot tests at the engineering scale for other types of waste.

Min and Zhaoxiang (1992) reported on studies that were conducted with 1AW-MTR waste solution. The effects of acid strength, temperature, flow rate, and cycling on the loading capacity of polyantimonic acid were investigated. From $0.5-4 \mathrm{M} \mathrm{HNO}_{3}$, no real effect on strontium loading was observed. Temperature $\left(13^{\circ} \mathrm{C}-63^{\circ} \mathrm{C}\right)$, flow rate $(0.5-4$ column volumes/hour), and cycling had great effects on loading. The highest loadings, $0.22 \mathrm{mmol} / \mathrm{g}$, were observed at 0.5 column volumes/hour and $63^{\circ} \mathrm{C}$ (i.e., reported at $1 \%$ strontium breakthrough). Elution was possible with $8 \underline{\mathrm{M}} \mathrm{HNO}_{3}$ and $0.5 \underline{\mathrm{M}} \mathrm{AgNO}_{3}$.

\subsection{Sodium Titanate}

The use of sodium titanate to remove strontium from alkaline Hanford waste solutions has been investigated in the past (Strachan and Schulz 1980; Schulz 1980). In one of the studies conducted by Strachan and Schulz (1980), actual waste was used. The waste solution, adjusted to $1 \mathrm{M} \mathrm{NaOH}$, was passed through three columns loaded with sodium titanate. The strontium DFs were greater than 100 . No strontium breakthrough was observed in these tests after 1478 column volumes of feed had passed through the columns.

The study reported by Schulz (1980) was conducted on actual salt cake from eight different waste tanks. The conceptual process was termed the Hanford Radionuclide Removal Process. It involved ozonation to destroy organic complexants, precipitation of inert strontium phosphate to remove ${ }^{90} \mathrm{Sr}$ and other multivalent cations, removal of cesium by ARC-359 ion exchange, and sodium titanate ion exchange to remove residual strontium. In this study, both sodium titanate powder (40-140 mesh) and titanate-loaded macroreticular anion exchange beads were used. The hydrodynamic stability of the loaded beads was superior to the powder; however, due to the decreased amount of sodium titanate on the beads, the strontium removal/wt resin was greater for the sodium titanate powder.

Lehto and Miettinen (1984) conducted studies using sodium titanate to remove strontium from high salt $(215 \mathrm{~g} / \mathrm{L})$ waste solutions. Decontamination factors of 170 were reported. The kinetics of the sorption of strontium were also reported to be very favorable (i.e., $t_{1 / 2}=1.2 \mathrm{~min}, 0.001 \underline{\mathrm{M}}$ strontium in feed). The ion exchange material showed no change in structure or in its ability to adsorb strontium

when exposed to an irradiation dose of $10^{7} \mathrm{~Gy}$. The presence of EDTA severely limited the sorption 
of strontium on the ion exchange column, while the presence of $0.005-0.05 \underline{\mathrm{M}}$ citrate had little or no effect on strontium sorption. Boric acid concentrations of $1 \underline{M}$ and sodium concentrations of $4 \underline{M}$ decreased the strontium distribution coefficient $(\mathrm{Kd})$ by $10 \mathrm{X}$, while lower concentrations had much less of an effect. It was noted that the spent sodium titanate ion exchange material could be 1) hot pressed or 2) mixed with clay and fired at $1000^{\circ} \mathrm{C}$ to form a viable solid waste.

In a similar study, the effectiveness of sodium titanate for removing strontium from LLW streams was evaluated (Ying, Meiqiong, and Xiannua 1984). In this study, the effects of calcium, sodium, and iron on the strontium distribution coefficient were investigated. The results indicated that the strontium distribution coefficient was not affected by sodium concentrations up to $4 \underline{\mathrm{M}}$, while iron and calcium concentrations greater than $10^{-3} \underline{\mathrm{M}}$ severely decreased the strontium distribution coefficient. The presence of various organic complexing agents (e.g., EDTA) led to a significant decrease in strontium adsorption on sodium titanate. Irradiation tests were also conducted, and it was determined that the strontium distribution ratio did not change for the conditions tested. It was suggested that the spent sodium titanate ion exchanger could be sintered at $1000^{\circ} \mathrm{C}$ to produce a translucent glass-like ceramic waste form.

Recently, a new class of materials that can selectively extract cesium and strontium from solutions has been developed by Robert G. Dosch and Rayford G. Anthony at Sandia National Laboratory (Baum 1992). The materials, silico-titanates or crystalline titanates were developed from work that was conducted in the 1970s. Also, the hydrous titanate ion exchangers developed at Savannah River and currently being used on a large scale (precipitation) at Savannah River grew out of this early work. Yet-to-be-published experimental results indicate that the silico-titanates show promise for separating cesium, strontium, and plutonium from alkaline, high sodium salt solutions.

\subsection{Macrocyclic Ligands}

Horwitz, Dietz, and Fisher (1991b) first investigated the use of macrocyclic polyethers (i.e., crown ethers) sorbed onto an inert substrate as an analytical technique for measuring strontium in a sample. The resin consisted of 4,4'(5')-bis(tert-butylcyclohexano)-18-crown-6 + octanol loaded onto Amberlite XAD-7, and has been given the trade name Sr-Spec (EIChroM Industries, Inc.). A strontium DF of 100 was obtained when 20 free column volumes (i.e., column void space volumes) of $3 \underline{\mathrm{M}} \mathrm{HNO}_{3}$ solution were introduced to a column containing Sr-Spec. In addition, over $98 \%$ of the loaded strontium was eluted in 2.5 free column volumes of deionized water. The presence of up to $2 \mathrm{X}$ more calcium than strontium in the feed had no effect on strontium loading or elution behavior. However, barium and lead were also adsorbed onto the resin. The lead was bound strongly by the column material. The strontium could be eluted by using deioinized water, while the lead was not. It was suggested that lead could then be eluted by using $0.1 \mathrm{M}$ sulfuric acid. The use of $2 \underline{\mathrm{M}} \mathrm{HNO}_{3}+0.5 \underline{\mathrm{M} \mathrm{AI}}\left(\mathrm{NO}_{3}\right)_{3}$ rather than $3 \underline{\mathrm{M}} \mathrm{HNO}_{3}$ to load strontium gave a strontium $\mathrm{DF}=100$ in the first 30 free column volumes of feed, while $>99 \%$ of the calcium passed through the column. 
In a later publication, a systematic examination of the selectivity of Sr-Spec for strontium over other alkali, alkaline earth, and other selected elements was conducted (Horwitz, Chiarizia, and Dietz 1992). Barium was the only alkaline earth element other than strontium that was retained by the resin; lead was more strongly retained by the resin than was strontium at all $\mathrm{HNO}_{3}$ concentrations studied (i.e., $10^{-2} \underline{\mathrm{M}}$ to $10 \underline{\mathrm{M}}$ ). Also, tetravalent plutonium, neptunium, and polonium were retained to a significant extent on the resin over the acid concentrations studied.

In a related study, Chiariza, Horwitz, and Fisher (1992) investigated the acid dependency of the extraction of selected metal ions by Sr-Spec. In this study, calculated acid dependencies and extraction constants were compared with experimental values.

Horwitz, Fisher, and Chiarizia (1992) have conducted tests using Sr-Spec to separate strontium from synthetic waste that simulates dissolved Hanford sludge waste. Decontamination factors (i.e., ratio of concentration of the test element in the feed to the concentration of the same element in the strontium product fraction) ranged from 100 for aluminum to $10^{5}$ for calcium. It was noted that longterm stability tests of the resin had not yet been done, and future work in that laboratory would focus more on process-scale treatment of strontium containing waste as opposed to isolation of strontium for analytical purposes.

Superlig 601 (IBC Advanced Technologies) is composed of a macrocyclic compound (proprietary compound) that is covalently attached to a silica gel support. Development work related to silica-gelbonded macrocycle systems is documented in the literature (Izatt et al. 1988; Bradshaw et al. 1988; Bradshaw et al. 1989a,b; Bruening et al. 1991).

Tests at PNL used Superlig $601(10 \mathrm{~g})$ to separate strontium and barium from a synthetic waste that simulated PUREX raffinate (Camaioni, Colton, and Bruening 1992). Nearly complete breakthrough occurred after 30 bed volumes $(450 \mathrm{~mL})$ of feed had passed through the column. In the elution steps, approximately $35 \%$ of the strontium was eluted with a $1 \underline{\mathrm{M} \mathrm{HNO}} \mathrm{H}_{3}$ wash. Approximately $35 \%$ of the barium was eluted in the $\mathrm{HNO}_{3}$ and $\mathrm{Na}_{3}$ citrate washes, and about $60 \%$ was removed in a subsequent $\mathrm{Na}_{4}$ EDTA wash. No flow rate was reported for these experiments. Visual evidence suggested that channeling of the feed in the column may have occurred.

Experiments were conducted by IBC (results presented in Camaioni, Colton, and Bruening 1992), using the same feed solution; however, in this case $20 \mathrm{~g}$ of Superlig 601 was used. A total of $450 \mathrm{~mL}$ of solution passed through the column, and no strontium breakthrough was noted. One hundred percent of the strontium was eluted using $\mathrm{HNO}_{3}$ (16 $\underline{\mathrm{M}}$ in this case) and $\mathrm{Na}_{3}$ citrate wash, while only $10 \%$ of the barium was eluted. The remainder of the barium was eluted by washing with $\mathrm{Na}_{4} \mathrm{EDTA}$. A flow rate of approximately $30 \mathrm{~mL} / \mathrm{min}$ was reported for these experiments.

The Superlig 601 data, presented above, data cannot be directly compared 1) because different quantities of Superlig 601 were used in the two cases, 2) in the elution step different $\mathrm{HNO}_{3}$ concentrations were used, and 3) channeling may have occurred in one case. 
Lumetta et al. (1993) evaluated both Superlig 601 and Sr-Spec for the removal of strontium from actual Hanford neutralized cladding removal waste (NCRW). Different column dimensions and flow rates were used in the studies for the two ion exchange materials; therefore, it is difficult to directly compare the results. No strontium was detected in the effluent after 7 column volumes had passed through a column containing Sr-Spec. Two flow rates, $0.1 \mathrm{~mL} / \mathrm{min}$. and $1.5 \mathrm{~mL} / \mathrm{min}$, were used in evaluating the strontium separation performance of Superlig 601. At the lower flow rate an overall strontium DF of approximately 250 was obtained for 17 bed volumes. At the higher flow rate a strontium DF of 20 for 17 column volumes was obtained, indicating that absorption kinetics at the higher flow rate was a limiting factor. It was demonstrated that $\mathrm{Na}_{3}$ citrate could selectively elute strontium from the column, and then the barium would be eluted using EDTA.

One advantage that Sr-Spec currently has over Superlig 601 is that no complexants are required for elution of strontium from Sr-Spec. It is difficult to evaluate the relative separation performances of the two resins based on the data that have been presented. Experiments under identical conditions (i.e., the same linear velocities, etc.) should be conducted to provide more information on the relative performance of these two ion exchange resins.

\subsection{Other Ion Exchange Methods}

DOWEX-50W, X-12 was used at Hanford to produce 1 megacurie of $98 \%{ }^{90} \mathrm{Sr}$ for use as the power source for five thermoelectric power units developed by the Martin company (Bray et al. 1960). The feed to the ion exchange column was strontium crude product that was produced by a process involving lead sulfate precipitation of the strontium, removal of the lead from the strontium, and redissolution of the strontium (Bray and Van Tuyl 1961; Richardson 1965). In the ion exchange process, the feed was adjusted to a $\mathrm{pH}=4$, and EDTA was added to prevent column adsorption of iron, lead, and lanthanides. The column was then eluted by using a $\mathrm{pH}=8$ solution that contained EDTA.

Bray et al. (1984) investigated the use of IRC-718, an organic macroporous cation exchanger, for removing strontium from West Valley alkaline waste. In batch tests it was found that strontium was much more effectively removed from solution at $\mathrm{pH}=10$ as compared with $\mathrm{pH}=13$. Flow tests were also conducted, using this ion exchanger, and these tests confirmed that strontium separation performance was dependent on feed $\mathrm{pH}$. The strontium was eluted with $2 \underline{\mathrm{M}} \mathrm{HCOOH}$.

Johnson (1985) compared the relative effectiveness of Duolite ES-286 (formerly C-26), Duolite ES-278, DOWEX-50W, X-8 (similar to DOWEX-50W, X-12), and IRC-718 for removing strontium from streams containing lanthanides and other metal ions, including magnesium and calcium. In batch studies, it was found that Duolite ES-286 was superior to the other ion exchangers with respect to strontium selectivity over the lanthanides and other alkaline earth metals. However, the addition of EDTA in $20 \%$ excess of the lanthanides and alkaline earth metals was necessary to achieve the separation of strontium from the other metals. Column testing of the Duolite ES-286 ion exchange material was also conducted. At a flow rate of 1 bed volume/hour, using simulated waste, $1 \%$ breakthrough 
occurred after 3 bed volumes had passed through the column. The strontium that had been removed from solution could be eluted with approximately 10 bed volumes of 2 to $3 \underline{\mathrm{M}} \mathrm{HNO}_{3}$ or aluminum nitrate.

Pilot runs using CS-100 (an organic ion exchanger) to remove strontium and cesium from LLW were conducted by Carley-Macauly et al. (1981). In these tests, interfering bulk cations, such as calcium, manganese, etc., were precipitated and removed from solution upstream of the ion exchange process by adjusting the feed stream to $\mathrm{pH}=11.8$. The strontium and cesium were eluted from the column by using $0.5 \mathrm{M} \mathrm{HNO}_{3}$. Campbell, Lee, and Dillow (1990) also reported favorable results for the removal of strontium from LLW using CS-100. They reported that the presence of sodium decreased the removal of strontium from solution, while the presence of potassium had little effect on strontium removal. Bray et al. (1984) reported that very little strontium was removed from solution when CS-100 was tested in batch and column operation.

Bray et al. (1984) also tested the effectiveness of IE-95 (a zeolite-based ion exchanger) for removing strontium from simulated West Valley alkaline waste. They found that the strontium removal from solution was lower at $\mathrm{pH}=10$ as compared with $\mathrm{pH}=13$. Column flow-through tests indicated that kinetic and equilibrium problems affected strontium sorption. The cesium and strontium were eluted with $4 \underline{\mathrm{M}} \mathrm{HNO}_{3}$.

Modified versions of IE-95 are now available. IE-96 contains approximately $1 \%$ calcium compared with $4 \%$ calcium in IE-95. With the higher calcium in IE-95, calcium carbonate precipitates when contacted with wastes high in carbonate (i.e., typical of Hanford wastes). TIE-96 is basically IE-96 that is "coated" with a titanate layer. The titanate acts to remove strontium and plutonium from solution, while the cesium "passes" through the titanate layer and is removed from solution by the zeolite portion of the exchanger (i.e., IE-96). Some strontium is also removed by the zeolite portion of the exchanger as well. Resuits have been reported on the use of TIE-96 for the removal of cesium, strontium, and plutonium from West Valley waste (Bray and Hara 1991). In the same study, commercial production of TIE-96 was investigated, and the technology was transferred to a large-scale ion exchange manufacturer.

The use of Chelex-100 has been investigated for removing strontium from alkaline solution (Blount et al. 1973; Wiley 1976). In pilot-scale tests, performed on actual Savannah River Plant waste, relatively high strontium DFs were reported (Wiley 1976). It was also reported that calcium, iron, manganese, and zinc interfered with the removal of strontium.

Screening tests have involved various ion exchangers (Phillips et al. 1984; Hooper 1985). From batch tests, titanium phosphate, manganese oxide, and titanium oxide showed promise for removing strontium from alkaline solutions. The influence of kinetics and interfering ions was not evaluated in these tests and would have to be addressed. Radiation exposure tests were conducted, and it was determined that these ion exchangers were resistant to radiation damage for the conditions studied. 
Recently, Paulus, Komarneni, and Roy (1992) briefly described a method for synthesizing $\mathrm{Na}_{4} \mathrm{Mg}_{6} \mathrm{Al}_{4} \mathrm{Si}_{4} \mathrm{O}_{20} \mathrm{~F}_{4}$ mica. Batch contact experiments were also conducted to determine the effectiveness of this ion exchanger for removing strontium from solution. Preliminary results indicated that strontium could be removed from streams high in sodium. In addition, selectivity of strontium over magnesium and calcium was indicated. The $\mathrm{pH}$ ranges of the experiments were not noted in this article.

\subsection{Suggested Future Development}

On the acid side, polyantimonic acid, Superlig 601, and Sr-Spec showed affinities for strontium. Polyantimonic showed promise in batch contacts; however, slow kinetics severely limits its use on a large scale. Superlig 601 requires the use of complexants for elution. Based on current information, it appears that $\mathrm{Sr}$-Spec shows the most promise of the three for removing strontium from acidic solutions. It has been reported, however, that lead and barium interfere with strontium removal from solution. Tests should be conducted on the radiolytic and chemical stability of the macrocyclic resins in particular.

Numerous ion exchange technologies have been tested for alkaline-side strontium removal. Sodium titanate appears to be very effective for removing strontium from alkaline waste streams. It was observed, however, that iron, calcium, and complexants interfere with strontium uptake by the ion exchanger. Sodium titanate was resistant to radiation damage. It was also reported that silico-titanates have a great affinity for cesium and strontium from alkaline wastes, but published results are not yet available.

IRC-718 showed great affinity for strontium; however, relatively small changes in feed pH dramatically affect the removal of strontium from solution. The performance of CS-100 for the removal of strontium was mixed. Also, being organic exchangers, CS-100 and IRC-718 may be prone to radiolytic degradation. ES-286 showed superior strontium separation from lanthanides and other alkaline earth metals (at $\mathrm{pH}=8.0$ ) when compared with Duolite ES-278, DOWEX-5OW, X-8, and IRC-718. However, in order to achieve this separation, the addition of EDTA to the feed solution was required. Chelex-100 showed promise for removing strontium from solution; however, calcium, iron, manganese and zinc were also removed by this exchanger.

IE-95 was also effective in removing strontium from alkaline solution in batch tests; however in column tests, slow kinetics appeared to be a problem. Newer versions of IE-95 are now available, i.e., IE-96 and TIE-96. Both of these versions should be tested on a laboratory scale. TIE-96, in particular, is attractive because conceptually it should be capable of removing cesium, strontium, and plutonium.

Several other ion exchangers, such as titanium phosphate, manganese oxide, and hydrous titanium oxide, showed promise in batch tests for removing strontium from alkaline wastes. Kinetic evaluation 
and species interferences are required to further evaluate the effectiveness of these ion exchangers for removing strontium. Tests indicated that these ion exchangers were resistant to radiation damage.

Based on current information, it appears that sodium titanate is the preferred ion exchanger on the alkaline side. There is concern over the hydrodynamic stability of the sodium titanate powder in the column; therefore, alternative support systems for this ion exchange system should be investigated. The silico-titanates, IE-96, TIE-96, titanium phosphate, manganese dioxide, and hydrous titanium oxide, and $\mathrm{Na}_{4} \mathrm{Mg}_{6} \mathrm{Al}_{4} \mathrm{Si}_{4} \mathrm{O}_{20} \mathrm{~F}_{4}$ mica exchangers should be also be evaluated because either no published data or little data are presently available for these exchangers.

Before any one of these exchangers can be chosen, the capacity, kinetics, stability, and selectivity of the exchangers must be investigated. Also, cost and waste production, although not investigated here, must still be addressed.

Other recommended future development steps are given below.

- For alkaline-side processing, conduct studies to determine the effects of complexants (e.g., EDTA) on strontium separation.

- Conduct laboratory (batch and column) studies using simulated waste.

- Investigate the degree of chemical and radiolytic degradation of the resin(s).

- Develop flowsheets using laboratory test results as applied to actual wastes. 


\subsection{Conclusions}

Several promising methods were identified for removal of strontium from alkaline and acidic media. In all cases, however, additional development is required. In particular, testing with simulated and actual Hanford waste is required prior to implementation. Furthermore, the effect of complexants such as EDTA on the various alkaline-side separation methods must be evaluated. 


\subsection{References}

10 CFR 61. 1988. U.S. Nuclear Regulatory Commission, "Licensing Requirements for Land Disposal of Radioactive Waste." U.S. Code of Federal Regulations.

Baum, R. 1992. "Cesium Cut From Radioactive Waste." Chemical Engineering Progress 88(9):26.

Baetsle, L. H., D. Huys, and P. Speeckaert. 1973. Separation of ${ }^{137} \mathrm{Cs}$ and ${ }^{90} \mathrm{Sr}$ from Highly Radioactive Fission Product Solutions. BLG-487, Centre d'Etudes de l"Energie Nucleare, Mol (Belgium).

Baetsle, L. H., D. Van Deyck, D. Huys, and A. Guery. 1965. Studies on the Separation of ${ }^{137}$ Cs and ${ }^{90}$ Sr from Fission Production in an Acid Medium on Mineral Ion Exchangers. EUR 2497.e, European Atomic Energy Community - Euratom.

Blasius, E., W. Klein, and U. Schon. 1985. "Separation of Strontium from Nuclear Waste Solutions by Solvent Extraction with Crown Ethers." Journal of Radioanalytical and Nuclear Chemistry, Articles 89(2):389-398.

Blount, C. W., D. E. Leyden, T. L. Thomas, and S. M. Guill. 1973. "Application of Chelating Ion Exchange Resins for Trace Element Analysis of Geological Samples Using X-Ray Fluorescence." Analytical Chemistry (45)7:1045-1050.

Bradshaw, J. S., R. L. Bruening, K. E. Krakowiak, B. J. Tarbet, M. L. Bruening, R. M. Izatt, and J. J. Christensen. 1988. "Preparation of Silica Gel-bound Macrocycles and Their Cation-binding Properties." J. Chem. Soc. Chem. Commun.(12):812-813.

Bradshaw, J. S., K. E. Krakowiak, B. J. Tarbet, R. L. Bruening, J. F. Biernat, M. Bochenska, R. M. Izatt, J. J. Christensen. 1989a. "Silica Gel-bound Aza-crowns for the Selective Removal and Concentration of Metal Ions." Pure \& Applied Chem. 61(9):1619-1624.

Bradshaw, J. S., K. E. Krakowiak, B. J. Tarbet, R. L. Bruening, L. D. Griffin, D. E. Cash, T. D. Rasmussen, and R. M. Izatt. 1989b. "New Nitrogen-containing Macrocyclic Ligands Covalently Attached to Silica Gel and Their Use in Separating Metal Cations." Solvent Extraction and Ion Exchange 7(5):855-864.

Bray, L. A., and F. T. Hara. 1991. "Use of Titanium-treated Zeolite for Plutonium, Strontium, and Cesium Removal from West Valley Alkaline Wastes and Sludge Wash Waters.” PNL-SA-19696 S, Pacific Northwest Laboratory, Richland, Washington. 
Bray, L. A., and H. H. Van Tuyl. 1961. Laboratory Development of a Carrier - Precipitation Process for the Recovery of Strontium from PUREX Wastes. HW-69534, Hanford Atomic Products Operation, Richland, Washington.

Bray, L. A., L. K. Holton, T. R. Meyers, G. M. Richardson, and B. M. Wise. 1984. Experimental Data Developed to Support the Selection of a Treatment Process for West Valley Alkaline Supernatant. PNL-4969, Pacific Northwest Laboratory, Richland, Washington.

Bray, L. A., L. F. Lust, R. L. Moore, F. P. Roberts, F. M. Smith, H. H. Van Tuyl, and E. J. Wheelwright. 1961. The Recovery and Purification of Multi-kilocurie Quantities of Fission Product Strontium by Cation Exchange. HW-70998, Hanford Atomic Products Operation, Richland, Washington.

Bruening, M. L., D. M. Mitchell, J. S. Bradshaw, and R. M. Izatt. 1991. "Effect of Organic Solvent and Anion Type on Cation Binding Constants with Silica Gel Bound Macrocycles and Their Use in Designing Selective Concentrator Columns." Anal. Chem. 63:21-24.

Camaioni, D. M., N. G. Colton, and R. L. Bruening. 1992. Investigation of the Potential of Silicabonded Macrocyclic Ligands for Separation of Metal Ions from Nuclear Waste. PNL-7894, Pacific Northwest Laboratory, Richland, Washington.

Campbell, D. O., D. D. Lee, and T. A. Dillow. 1990. "Low-Level Waste Decontamination by Ion Exchange." Waste Management '90 1:389-398.

Carley-Macauly, K. W., R. G. Gutman, E. W. Hooper, J. A. Jenkins, A. D. Turner, P. F. Wace, P. Chauvet, J. P. Gauchon, and T. Dippel. 1981. Radioactive Waste: Advanced Management Methods for Medium Active Liquid Waste.

Chiarizia R., E. P. Horwitz, and D. E. Fisher. 1992. "Acid Dependency of the Extraction of Selected Metal Ions by a Strontium-selective Extraction Chromatographic Resin: Calculated vs. Experimental Curves." Solvent Extraction and Ion Exchange 10(2):337-361.

Davis, D. K., J. A. Partridge, and O. H. Koski. 1977. Selection and Evaluation of Processes for Recovery of Beneficial Isotopes from Commercial Reactor Wastes. BNWL-2063, Pacific Northwest Laboratory, Richland, Washington.

Esimantovskii, V. M., B. Y. Galkin, E. G. Dzekun, L. N. Lazarev, R. I. Lybtsev, V. N. Romanovskii, and D: N. Shishkin. 1992. "Technological Tests of HAW Partitioning with the Use of Chlorinated Cobalt Dicarbolide (CHCODIC); Management of Secondary Wastes." In Proceedings of International Symposium, Waste Management 1992. March 1-5, 1992, Tucson, Arizona. 
Filippov, E. A., E. G. Dzekun, A. K. Nardova, and I. V. Mamakin. 1992. "Application of CrownEthers and Ferrocyanide-based Inorganic Material for Cesium and Strontium Recovery from HighLevel Radioactive Wastes.” Waste Management 92:1021.

Gerber, M. A. 1992. Review of Technologies for the Pretreatment of Retrieved Single-Shell Tank Waste at Hanford. PNL-7810, Pacific Northwest Laboratory, Richland, Washington.

Gerow, I. H., and M. W. Davis. 1979. "The Use of 24-Crown-8's in the Solvent Extraction of $\mathrm{CsNO}_{3}$ and $\mathrm{Sr}\left(\mathrm{NO}_{3}\right)_{2}$." Separation Science and Technology 14(5):395-414.

Gerow; I. H., J. E. Smith, and M. W. Davis. 1981. "Extraction of $\mathrm{Cs}^{+}$and $\mathrm{Sr}^{2+}$ from $\mathrm{HNO}_{3}$ Solution Using Macrocyclic Polyethers.” Separation Science and Technology 16(5):519-548.

Grossi, G., L. Pietrelli, and F. Troiani. 1992. Selective Separation of Actinides and Long-lived Fission Products from 1-AW MTR Liquid Waste: Process Development. EUR 13644/1, Rome, Italy.

Grossi, G., A. Marrocchelli, L. Pietrelli, C. Calle, M. Gili, A. Luce, and F. Troiani. 1992. Selective Separation of Actinides and Long-lived Fission Products from I-AW MTR Liquid Waste: Pilot Plant Tests. EUR 13644/2, Rome, Italy.

Gutman, R. G., I. W. Cumming, G. H. Williams, R. H. Knibbs, I. M. Reed, P. Biddle, C. G. Davison, J. W. Sharps, M. Smith, J. A. Jenkins, J. A. Blackwell, T. E. Hilton, and C. E. Barclay. 1986. Active Liquid Treatment by a Combination of Precipitation and Membrane Processes. EUR 10822, Harwell, Oxon, United Kingdom.

Hill, O. F. 1963. Hot Semiworks Strontium-90 Recovery Program. HW-72666, Hanford Atomic Products Operation, Richland, Washington.

Hooper, E. W. 1985. "The Application of Inorganic Ion Exchangers to the Treatment of Medium Active Effluents." Solvent Extraction and Ion Exchange in the Nuclear Fuel Cycle, pp. 145-155.

Horner, D. E., D. J. Crouse, K. B. Brown, and B. Weaver. 1963. "Solvent Extraction Chemistry Symposium, Part II Fission Product Recovery from Waste Solutions by Solvent Extraction.” Nuclear Science and Engineering 17:234-246.

Horwitz, E. P. 1991. Combining Extractant Systems for the Simultaneous Extraction of Transuranic Elements and Selected Fission Products. ANL/CP-73631, Argonne National Laboratory, Argonne, Illinois.

Horwitz, E. P., M. L. Dietz, and D. E. Fisher. 1990a. "Correlation of the Extraction of Strontium Nitrate by a Crown Ether with the Water Content of the Organic Phase." Solvent Extraction and Ion Exchange 8(1):199-208. 
Horwitz, E. P., M. L. Dietz, and D. E. Fisher. 1990b. "Extraction of Strontium from Nitric Acid Solutions Using Dicyclohexano-18-Crown-6 and Its Derivatives." Solvent Extraction and Ion Exchange 8(4\&5):557-572.

Horwitz, E. P., M. L. Dietz, and D. E. Fisher. 1991a. "SREX: A New Process for the Extraction and Recovery of Strontium from Acidic Nuclear Waste Streams." Solvent Extraction and Ion Exchange 9(1):1-25.

Horwitz, E. P., M. L. Dietz, and D. E. Fisher. 1991b. "Separation and Preconcentration of Strontium from Biological, Environmental, and Nuclear Waste Samples by Extraction Chromatography Using a Crown Ether." Analytical Chemistry 63:522-525.

Horwitz, E. P., R. Chiarizia, and D. E. Fisher. 1992. "A Novel Strontium-selective Extraction Chromatographic Resin.” Solvent Extraction and Ion Exchange 10(2):313-336.

Horwitz, E. P., D. E. Fisher, and R. Chiarizia. 1992. "The Application of Novel Extraction Chromatographic Materials to the Characterization of Radioactive Waste Solutions." Journal of Radioanalytical and Nuclear Chemistry, Articles 161(2):575-583.

Izatt, R. M., R. L. Bruening, M. L. Bruening, B. J. Tarbet, K. E. Krakowiak, J. S. Bradshaw, and J. J. Christensen. 1988. "Removal and Separation of Metal Ions from Aqueous Solutions Using a Silica-gel-bonded Macrocycle System.” Anal. Chem. 60:1825-1826.

Johnson, M. E. 1985. Strontium Ion Exchange Feasibility Study. SD-WM-ER-018, Rockwell Hanford Operations, Richland, Washington.

Kolarik, Z. 1991. Separation of Actinides and Long-Lived Fission Products from High Level Radioactive Wastes (A Review). KfK4945, Kernforschungszentrum Karlsruhe GmbH, Karlsruhe.

Koprda, V., and V. Scasnar. 1983. "Extraction of Radiostrontium from the Mixture of Radionuclides in Milk Using Dicarbolide of Cobalt.” Journal of Radioanalytical Chemistry 77(1):71-78.

Koprda, V, V. Scansar, and P. Galan. 1983. ${ }^{\text {"Separation of }}{ }^{137} \mathrm{Cs}$ and ${ }^{90} \mathrm{Sr}$ from Mineralizates of Biological Materials by Dicarbolide of Cobalt." Journal of Radioanalytical Chemistry 80(1):55-62.

Lee L., and L. L. Kilpatrick. 1982. A Precipitation Process for Supernate Decontamination. DP-1636, Savannah River Laboratory, Aiken, South Carolina.

Lehto, J., and J. K. Miettinen. 1984. A Highly Selective Inorganic Ion Exchanger for Strontium. IAEA-TECDOC-337:9, International Atomic Energy Agency, Vienna, Austria. 
Lumetta, G. J., D. W. Wester, J. R. Morrey, and M. J. Wagner. 1993. “Preliminary Evaluation of Chromatographic Techniques for the Separation of Radionuclides from High-Level Radioactive Waste." Solvent Extr. Ion Exch. 11:663-682.

Lumetta, G. J., L. A. Bray, D. E. Kurath, J. R. Morrey, J. L. Swanson, and D. W. Wester. 1991. Exploratory CC Waste Process Study: Report for FY 1991. PNL-8438, Pacific Northwest Laboratory, Richland, Washington.

Martin, H. D., M. A. Schmitz, M. A. Ebra, D. D. Walker, and L. L. Kirkpatrick. 1984. "Tank Precipitation Process for Decontamination of Water Soluble Radioactive Waste." Waste Management '84 (Proc. Int. Symp. Tucson) 1:291-296.

McDowell, W. J., B. A. Moyer, G. N. Case, and F. I. Case. 1986. "Selectivity in Solvent Extraction of Metal Ions by Organic Cation Exchangers Synergized by Macrocycles: Factors Relating to Macrocycle Size and Structure." Solvent Extraction and Ion Exchange 4(2):217-236.

McKee, R. W., H. K. Elder, R. F. McCallum, D. J. Silviera, J. L. Swanson, and L. E. Wiles. 1983. A Systems Study of the Feasibility of High-Level Nuclear Waste Fractionation for Thermal Stress Control in a Geologic Repository, Vlume 2. PNL-4530, Pacific Northwest Laboratory, Richland, Washington.

Min, W. Hao, and Sun Zhaoxiang. 1992. "Recovery of Cesium and Strontium from Acidic HLW from Power Reactors with Inorganic Ion Exchangers." Waste Management '92 2:1631-1634.

Myasoedova, T. G., M. Y. Ikonnikov, A. V. Ponomarev, P. A. Zagorets, and E. A. Fillipov. 1987. "Extraction of $\mathrm{Sr}^{2+}, \mathrm{Cs}^{+}$, and $\mathrm{Tl}^{+}$by Macrocyclic Polyesters from Nitric Acid Solutions." Radiokhimiya (translated) 29(2):180-183.

Paulus, W. J., S. Komarneni, and R. Roy. 1992. "Bulk Synthesis and Selective Exchange of Strontium Ions in $\mathrm{Na}_{4} \mathrm{Mg}_{6} \mathrm{Al}_{4} \mathrm{Si}_{4} \mathrm{O}_{20} \mathrm{~F}_{4}$ Mica." Nature 357:571-573.

Phillips, B. A., E. W. Hooper, S. P. Dagnall, and N. P. Monckton. 1984. Study of the Behavior of Inorganic Ion Exchangers in the Treatment of Medium Active Effluents: Part I: Preliminary Experimental Work on Absorber Preparation and Performance. AERE-G 2872, Harwell, Oxon, United Kingdom.

Pietrelli, L., and F. Troiani. 1990. "Chemical Treatment of High-Level Radioactive Liquid Waste Produced by an MTR Reprocessing Plant.” Waste Management 10:103-109.

Pietrelli, L., G. Grossi, and F. Troiani. 1988. "Selective Separations of Actinides and Long Lived Fission Products from Aged Liquid Wastes Produced by the EUREX Plant at Saluggia." In Management of Low and Intermediate Level Radioactive Wastes 1988 (Proc. Int. Symposium) 2:41-58. 
Pietrelli, L., G. Grossi, G. Torri, and A. Donato. 1986. "Process Selection Study for the Decontamination of Liquid HLW Produced by EUREX Pilot Plant." In Spectrum '86 Proc. ANS Int. Topical Meeting Waste Manage. Decont. Decomm, Niagara Falls, New York, September 14-18, 1986. CONF-860905, Vol. 1, pp. 1085-1095.

Rais, J., E. Sebestova, P. Selucky, and M. Kyrs. 1976. "Synergistic Effect of Polyethyleneglycols in Extraction of Alkaline Earth Cations by Nitrobenzene." J. Inorg. Nucl. Chem. 38:1742-1744.

Reilly, S. D., C.F.V. Mason, and P. H. Smith. 1990. Cobalt(III) Dicarbolide: A Potential ${ }^{137} \mathrm{Cs}$ and ${ }^{90}$ Sr Waste Extraction Agent. LA-11695, Los Alamos National Laboratory, Los Alamos, New Mexico.

Richardson, G. L. 1964. Solvent Extraction of Strontium, Cerium and Rare Earths with D2EHPA Part 1: Pilot Plant Studies. HW-79762 PT2, Hanford Atomic Products Operation, Richland, Washington.

Richardson, G. L. 1965. Recovery of Strontium from Stored PUREX Waste by Lead Sulfate Carrier Precipitation - Pilot Plant Studies. BNWL-4, Pacific Northwest Laboratory, Richland, Washington.

Scansar, V., and V. Koprda. 1980. "Isolation of ${ }^{137} \mathrm{Cs}$ from Excreta by Dicarbolide of Cobalt." Journal of Radioanalytical Chemistry 59(2):389-398.

Schulz, W. W. 1964. Solvent Extraction of Strontium, Cerium and Rare Earths with D2EHPA Part 1: Laboratory Studies. HW-79762 PT1, Hanford Atomic Products Operation, Richland, Washington.

Schulz, W. W. 1980. Removal of Radionuclides from Hanford Defense Waste Solutions. RHO-SA-51, Rockwell Hanford Operations, Richland, Washington.

Schulz, W. W., and L. A. Bray. 1987. "Solvent Extraction Recovery of Byproduct ${ }^{137} \mathrm{Cs}$ and ${ }^{90} \mathrm{Sr}$ from $\mathrm{HNO}_{3}$ Solutions - A Technology Review and Assessment." Separation Science and Technology 22(2\&3):191-214.

Schulz, W. W., J. E. Mendel, and G. L. Richardson. 1963. "Solvent Extraction Recovery and Purification of Strontium-90." I\&EC Process Design and Development 2(2):134-140.

Selucky, P., P. Vanura, J. Rais, and M. Kyrs. 1979. “A Rapid Method for the Separation of ${ }^{90} \mathrm{Sr}$ for Its Determination in a Mixture with Long-lived Fission Products." Radiochem. Radioanal. Letters 38(4):297-302.

Shuler, R. G., C. B. Bowers, J. E. Smith, V. Van Brunt, and M. W. Davis. 1985. “The Extraction of Cesium and Strontium from Acidic High Activity Nuclear Waste Using a Purex Process Compatible Organic Extractant." Solvent Extraction and Ion Exchange 3(5):567-604. 
Straalsund, J. L., J. L. Swanson, E. G. Baker, J. J. Holmes, E. O. Jones, and W. L. Kuhn. 1992. Clean Option: An Alternative Strategy for Hanford Tank Waste Remediation, Volume 1. Overview. PNL-8388 Vol. 1, Pacific Northwest Laboratory, Richland, Washington.

Strachan, D. M., and W. W. Schultz. 1980. Removal of Radionuclides from the Water-soluble Fraction of Hanford Nuclear Defense Wastes. RHO-SA-145, Rockwell Hanford Operations, Richland, Washington 99352.

Wischow, R. P., and D. E. Horner. 1962. Recovery of Strontium and Rare Earths from PUREX Waste by Solvent Extraction. ORNL-3204, Oak Ridge National Laboratory, Oak Ridge, Tennessee.

Wiley, J. R. 1976. Decontamination of Savannah River Plant Waste Supernate. DP-1436, Savannah River Laboratory, Aiken, South Carolina.

Ying, Y., L. Meiqiong, and F. Xiannua. 1984. Treatment of Liquid Wastes Containing Actinides and Fission Products Using Sodium Titanate as an Ion Exchanger. IAEA-TECDOC-337:223, International Atomic Energy Agency, Vienna, Austria. 


\section{Appendix}

\section{Tabular Summary of Literature Survey}


Table A.1. Solvent Extraction: Crown Ethers

\begin{tabular}{|c|c|c|c|}
\hline $\begin{array}{l}\text { Literature } \\
\text { Source }\end{array}$ & Experimental Conditions $^{(a)}$ & $\mathrm{D}_{\mathrm{Sr}}{ }^{(b)}$ & Comments \\
\hline $\begin{array}{l}\text { Gerow and Davis } \\
\text { (1979) }\end{array}$ & $\begin{array}{l}25 \% \text { Kerosene, } \\
25 \% \text { TBP, } \\
50 \% \text { HDEHP, } \\
0.02 \underline{\mathrm{M}} 4,4^{\prime}\left(5^{\prime}\right) \text { ditertiary-butylbenzo-24-C-8 } \\
0.001 \underline{\mathrm{M} S \mathrm{SO}_{3}} \\
\mathrm{pH}=3-5.5\end{array}$ & 200 & $\begin{array}{l}\text { Efficiently stripped at } \mathrm{pH}<2 \text {; } \\
\text { The highest } \mathrm{pH} \text { investigated was } 5.5 \text {, there } \\
\text { was no indication that the } \mathrm{D}_{\mathrm{Sr}} \text { decreased at } \\
\text { higher pHs. } \\
\text { No significant extraction without HDEHP. } \\
\text { In the absence of crown ether (e.g., HDEHP } \\
\text { only as extractant), a } \mathrm{D}_{\mathrm{Sr}} \text { of } 30 \text { was } \\
\text { extrapolated from the data ( } 25 \% \mathrm{TBP}, 50 \% \\
\text { HDEHP in kerosene, } \mathrm{pH}=\text { not given). }\end{array}$ \\
\hline $\begin{array}{l}\text { Gerow, Smith and } \\
\text { Davis } \\
\text { (1981) }\end{array}$ & $\begin{array}{l}68 \% \text { Kerosene, } \\
27 \% \text { TBP, } \\
5 \% \text { HDDNS, } \\
0.02 \underline{\mathrm{M}} \text { bis-(4,4'(5')-[1-hydroxyheptyl]-benzo)-18-C-6 } \\
.001 \underline{\mathrm{M}} \mathrm{SrNO}_{3} \\
<0.01 \underline{\mathrm{M}} \mathrm{HNO}_{3}\end{array}$ & 200 & $\begin{array}{l}\text { In the absence of } \mathrm{HDDNS} \text {, very low } \mathrm{D}_{\mathrm{Sr}} \\
\text { were observed with any crown ether. } \\
\text { Numerous crown ethers were tested with } 1 \% \\
\text { HDDNS and } \mathrm{pH}=2.5 \text {, and all crown ethers } \\
\text { tested gave } 4<\mathrm{D}_{\mathrm{Sr}}<6 \text {. Increasing HDDNS } \\
\text { concentration, substantially increased } \mathrm{D}_{\mathrm{Sr}} \\
\text { The presence of crown ether had little effect } \\
\text { on Sr extraction, } \mathrm{D}_{\mathrm{Sr}} \text { was affected most by } \\
\text { the presence of HDDNS. }\end{array}$ \\
\hline $\begin{array}{l}\text { Blasius, Klein and } \\
\text { Schon } \\
\text { (1985) }\end{array}$ & $\begin{array}{l}\text { Dicyclohexo-18-crown-6 in } \\
1,1,2 \text { Tetrochloroethane } \\
2 \mathrm{ppm} \mathrm{SrNO} \text {, } \\
1.0 \underline{\mathrm{MNO}} \mathrm{HNO}_{3}\end{array}$ & 12 & $\begin{array}{l}\text { Lead and sodium were also extracted under } \\
\text { these experimental conditions. Several other } \\
\text { diluents were tested, however } 1,1,2,2- \\
\text { tetrachloroethane gave the best results. } \\
1,1,2,2 \text {-tetrachlorethane is not a desirable } \\
\text { diluent to use due to its toxicity and } \\
\text { generation of } \mathrm{HCl} \text { (corrosive) on radiolysis. }\end{array}$ \\
\hline
\end{tabular}


Table A.1. (contd)

\begin{tabular}{|c|c|c|c|}
\hline $\begin{array}{l}\text { Literature } \\
\text { Source }\end{array}$ & Experimental Conditions ${ }^{(a)}$ & $D_{S r}{ }^{(b)}$ & Comments \\
\hline $\begin{array}{l}\text { Shuler et al. } \\
\text { (1985) }\end{array}$ & $\begin{array}{l}5 \% \text { HDNNS, } \\
27 \% \text { TBP, } \\
68 \% \text { kerosene, } \\
0.02 \underline{\mathrm{M}} \text { bis } 4,4^{\prime}\left(5^{\prime}\right) \text { (1-hydroxyheptyl)cyclohexo-18-C-6 } \\
0.003 \underline{\mathrm{M} \mathrm{Sr}} \\
3.0 \underline{\mathrm{MNO}} \mathrm{HN}_{3}\end{array}$ & 2 & $\begin{array}{l}\text { Higher } \mathrm{D}_{\mathrm{Sr}} \text { values were reported for higher } \\
\text { crown ether concentrations, e.g., } \mathrm{D}_{\mathrm{Sr}}=6.4 \\
\text { at } 0.1 \underline{\mathrm{M}} \mathrm{CE} \text {, however, a third phase formed } \\
\text { even though the solubility limit had not been } \\
\text { exceeded. } \\
\text { Zirconium and barium were also extracted. }\end{array}$ \\
\hline $\begin{array}{l}\text { McDowell et al. } \\
\text { (1986) }\end{array}$ & $\begin{array}{l}0.1 \underline{\mathrm{M}} \mathrm{HDDNS}, \\
0.05 \underline{\mathrm{M}} \text { di-tertiary-butylbenzo- } \\
18-\mathrm{C}-6 \text {, } \\
\text { Toluene } \\
\text { Tracer level Sr, } \\
0.2 \underline{\mathrm{MNO}} \mathrm{HN}_{3}\end{array}$ & 350 & $\begin{array}{l}\text { The presence of crown ether had a large } \\
\text { impact on } \mathrm{D}_{\mathrm{Sr}} \text { when compared to HDDNS } \\
\text { alone }\left(\mathrm{D}_{\mathrm{Sr}}=12\right) \text {. } \\
\mathrm{D}_{\mathrm{Sr}}=50 \text { at } \mathrm{HNO}_{3}=0.5 \underline{\mathrm{M}} \text {. } \\
\mathrm{D}_{\mathrm{Sr}}=1000 \text { at } \mathrm{HNO}_{3}=0.1 \underline{\mathrm{M}} \text { but precipitate } \\
\text { formed. } \\
\mathrm{D}(\mathrm{tBC}) 18-\mathrm{C}-6 \text { and } \mathrm{DC} 18-\mathrm{C}-6 \text { gave } \\
\mathrm{D}_{\mathrm{Sr}}>1000 \text { and } 0.2 \underline{\mathrm{M}}<\mathrm{HNO} \mathrm{O}_{3}<0.5 \underline{\mathrm{M}} \text {, but } \\
\text { precipitates formed. } \\
\text { Barium coextracted along with strontium. } \\
\text { At pH=8,0.1 versatic acid (organic } \\
\text { carboxylic acid) }+\mathrm{DC} 18-\mathrm{C}-6 \text { in toluene } \\
\text { gave } \mathrm{D}_{\mathrm{Sr}}=100 \text {. } \\
\text { Toluene has low flash point. }\end{array}$ \\
\hline $\begin{array}{l}\text { Myasoedova et al. } \\
\text { (1987) }\end{array}$ & $\begin{array}{l}0.05 \underline{\mathrm{M}} \text { dicyclohexyl-18-C-6 in } \\
\text { tetrachloro- } \\
\text { ethane } \\
0.025 \underline{\mathrm{M}} \mathrm{Sr}_{\left(\mathrm{NO}_{3}\right)_{2}} \\
3.0 \underline{\mathrm{MNO}} \mathrm{HN}_{3}\end{array}$ & 14 & $\begin{array}{l}\text { Tetrachlorethane is not a desirable diluent to } \\
\text { use due to its toxicity and generation of } \mathrm{HCl} \\
\text { (corrosive) on radiolysis. }\end{array}$ \\
\hline
\end{tabular}


Table A.1. (contd)

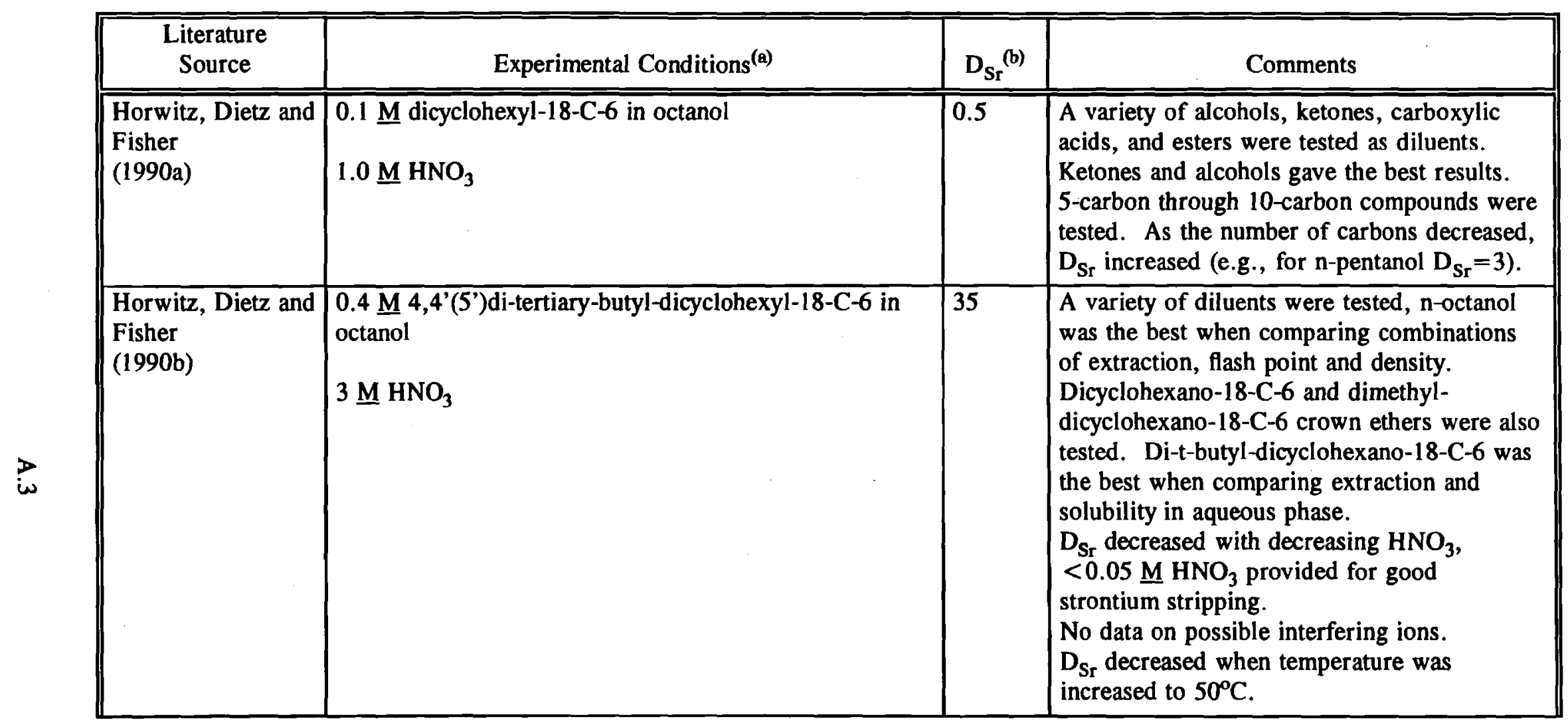


Table A.1. (contd)

\begin{tabular}{|c|c|c|c|}
\hline $\begin{array}{l}\text { Literature } \\
\text { Source }\end{array}$ & Experimental Conditions $^{(a)}$ & $\mathrm{D}_{\mathrm{Sr}}{ }^{(\mathrm{b})}$ & Comments \\
\hline $\begin{array}{l}\text { Horwitz, Dietz and } \\
\text { Fisher } \\
\text { (1991a) }\end{array}$ & $\begin{array}{l}0.2 \underline{\mathrm{M}} 4,4^{\prime}\left(5^{\prime}\right) \text { ditertiary-butyl-dicyclohexyl-18-C-6 in } \\
\text { octanol } \\
3 \underline{\mathrm{M} \mathrm{HNO}} 3\end{array}$ & 22 & $\begin{array}{l}\text { Synthetic waste, formulated to duplicate the } \\
\text { expected composition resulting from } \\
\text { dissolution of Hanford waste sludges was } \\
\text { used. } \\
\text { The system showed good hydrolytic stability. } \\
\text { At dose rates far in excess of those } \\
\text { anticipated in the process, } \mathrm{D}_{\mathrm{Sr}} \text { was adversely } \\
\text { affected. } \\
\text { The system showed good selectivity over } \\
\text { other metals. } \\
\mathrm{D}_{\mathrm{Sr}_{\mathrm{r}} \text { varied significantly from one lot of }} \\
\text { crown ether another. } \\
\text { At } 0.4 \mathrm{M} \text { crown ether, phase separation was } \\
\text { more difficult to attain. } \\
\text { Strontium selectivity increased or remained } \\
\text { the same with increasing acid from } 1 \text { M to } 6 \\
\mathrm{M} \text { HNO } \\
\mathrm{D}_{\mathrm{Ba}}>1 \text {, all other metals < } 1 \text { at the acid } \\
\text { concentrations investigated. } \\
\text { A } 3 \text { stage extraction, } 6 \text { stage scrub, and } 5 \\
\text { stage strip counter-current SX flowsheet } \\
\text { (SREX) was tested in the laboratory; } 99.7 \% \\
\text { Sr extracted. }\end{array}$ \\
\hline
\end{tabular}


Table A.1. (contd)

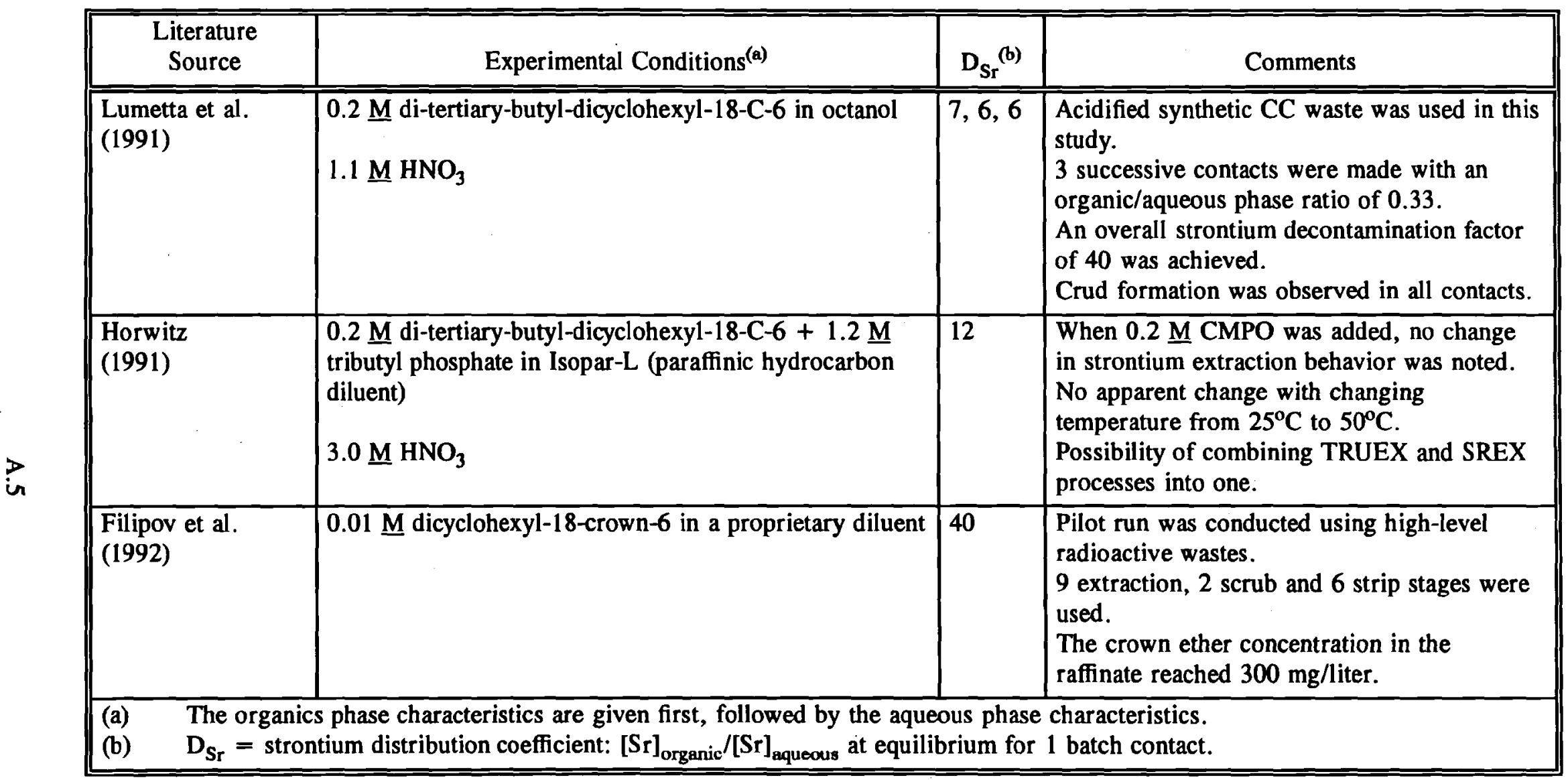


Table A.2. Solvent Extraction: Cobalt Dicarbolides

\begin{tabular}{|c|c|c|c|}
\hline $\begin{array}{l}\text { Literature } \\
\text { Source }\end{array}$ & Experimental Conditions $^{(a)}$ & $\mathrm{D}_{\mathrm{Sr}}{ }^{(\mathrm{b})}$ & Comments \\
\hline $\begin{array}{l}\text { Rais, Sebestova, } \\
\text { Selucky, and Kyrs. } \\
\text { (1976) }\end{array}$ & $\begin{array}{l}1.1 \times 10^{-2} \underline{\mathrm{M}} \text { cobalt dicarbolide }+ \\
0.2 \underline{\mathrm{M}} \mathrm{PEG}-400 \text { in nitrobenzene } \\
0.5 \underline{\mathrm{M}} \mathrm{HNO}_{3} .\end{array}$ & 60 & $\begin{array}{l}\text { Found that the presence of PEG- } 400 \text { increased } \\
\text { the extraction of strontium by } 1000 \mathrm{x} \text {. } \\
0.2 \mathrm{M} \text { PEG- } 400 \text { was optimum, higher and lower } \\
\text { concentrations gave less extraction. } \\
\text { Extraction of strontium decreased with } \\
\text { increasing PEG- } 400 \text { molecular weight. } \\
\text { Degree of extraction: } \mathrm{Ba}^{2+}, \mathrm{Pb}^{2+}>\mathrm{Sr}^{2+}> \\
\mathrm{Ca}^{2+}>\mathrm{Cu}^{2+}, \mathrm{Mg}^{2+}>\mathrm{Ni}^{2+} .\end{array}$ \\
\hline $\begin{array}{l}\text { Selucky, Vanura, Rais, } \\
\text { and Kyrs. } \\
\text { (1979) }\end{array}$ & $\begin{array}{l}0.02 \underline{\mathrm{M}} \text { cobalt dicarbolide }+0.5 \% \text { PEG- } \\
400 \text { in nitrobenzene } \\
0.01 \underline{\mathrm{M}} \mathrm{Na}_{5} \mathrm{DTPA} \\
\mathrm{pH}=4.0 .\end{array}$ & 100 & $\begin{array}{l}\text { Found that the presence of } \mathrm{Na}_{5} \mathrm{DTPA} \\
\text { suppressed the coextraction of other metals such } \\
\text { as zirconium. } \\
\text { Strontium also complexes with } \mathrm{Na}_{5} \mathrm{DTPA} \text { at } \\
\text { higher pHs and therefore does not extract at } \\
\text { higher pHs. }\end{array}$ \\
\hline $\begin{array}{l}\text { Scasnar and Koprda. } \\
\text { (1980) }\end{array}$ & $\begin{array}{l}0.01 \underline{\mathrm{M}} \text { cobalt dicarbolide in nitrobenzene } \\
0.0 \underline{\mathrm{M}} \mathrm{HNO}_{3} \text {. }\end{array}$ & 350 & $\begin{array}{l}\text { Found that as } \mathrm{HNO}_{3} \text { concentration increased, } \\
\text { the extraction of strontium decreased } \\
\text { significantly. } \\
\text { At } 0 \mathrm{M} \mathrm{HNO}_{3}, \mathrm{D}_{\mathrm{Cs}}=250, \mathrm{D}_{\mathrm{K}}=24, \mathrm{D}_{\mathrm{Co}}=10.7 \text {, } \\
\mathrm{D}_{\mathrm{Zr}}=0.32 \text {. }\end{array}$ \\
\hline $\begin{array}{l}\text { Koprda, Scasnar and } \\
\text { Galan. } \\
\text { (1983) }\end{array}$ & $\begin{array}{l}0.01 \underline{\mathrm{M}} \text { cobalt dicarbolide }+0.25 \% \text { PEG- } \\
400 \text { in nitrobenzene } \\
0.5 \underline{\mathrm{M} \mathrm{HNO}_{3}} \text {. }\end{array}$ & 60 & --- \\
\hline
\end{tabular}


Table A.2. (contd)

\begin{tabular}{|c|c|c|c|}
\hline $\begin{array}{l}\text { Literature } \\
\text { Source }\end{array}$ & Experimental Conditions ${ }^{(a)}$ & $\mathrm{D}_{\mathrm{Sr}}{ }^{(b)}$ & Comments \\
\hline $\begin{array}{l}\text { Koprda and Scasnar. } \\
\text { (1983) }\end{array}$ & $\begin{array}{l}0.01 \underline{\mathrm{M}} \text { cobalt dicarbolide }+ \\
0.1 \% \text { PEG-400 in nitrobenzene } \\
0.1 \underline{\mathrm{M}} \mathrm{HNO}_{3} .\end{array}$ & 600 & ---- \\
\hline $\begin{array}{l}\text { Reilly, Mason and Smith } \\
\text { (1991) }\end{array}$ & $\begin{array}{l}\text { Chlorinated cobalt dicarbolide in } \\
\text { nitrobenzene. }\end{array}$ & -- & $\begin{array}{l}>95 \% \text { Sr removed from tests with simulants, } \\
>98 \% \text { Sr removed from tests with actual } \\
\text { wastes. } \\
\text { Exact experimental conditions were not given. }\end{array}$ \\
\hline $\begin{array}{l}\text { Esimantovskii et al. } \\
\text { (1992) }\end{array}$ & $\begin{array}{l}\text { Chlorinated cobalt dicarbolide in } \\
\text { nitrobenzene. }\end{array}$ & -- & $\begin{array}{l}>98 \% \text { Sr removed from tests with actual } \\
\text { wastes. } \\
\text { Exact experimental conditions were not given. }\end{array}$ \\
\hline $\begin{array}{l}\text { The organics phas } \\
\mathrm{D}_{\mathrm{Sr}}=\text { strontium }\end{array}$ & $\begin{array}{l}\text { characteristics are given first, follov } \\
\text { stribution coefficient: }[\mathrm{Sr}]_{\text {organic }} /[\mathrm{Sr}]\end{array}$ & aqueou & $\begin{array}{l}\text { hase characteristics. } \\
\text { n for } 1 \text { batch contact. }\end{array}$ \\
\hline
\end{tabular}


Table A.3. Solvent Extraction: HDEHP

\begin{tabular}{|c|c|c|c|}
\hline $\begin{array}{c}\text { Literature } \\
\text { Source }\end{array}$ & Experimental Conditions ${ }^{(\mathbf{a})}$ & $\mathrm{D}_{\mathrm{Sr}}{ }^{(b)}$ & Comments \\
\hline $\begin{array}{l}\text { Schulz, Mendel and } \\
\text { Richardson } \\
\text { (1963) }\end{array}$ & $\begin{array}{l}0.4 \underline{\mathrm{M}} \text { HDEHP }+ \\
0.2 \underline{\mathrm{M}} \text { TBP in Shell Spray Base } \\
\mathrm{pH}=4.7\end{array}$ & 15 & $\begin{array}{l}\text { Tests conducted on Crude } \mathrm{Sr}^{90} \text { concentrate to } \\
\text { develop chemical flowsheets for the Hanford } \\
\text { Hot Semiworks plant. } \\
\mathrm{Na}_{4} \text { EDTA or } \mathrm{Na}_{5} \mathrm{DTPA} \text { added to feed to } \\
\text { suppress extraction of lead, iron and other } \\
\text { fission products. } \\
\text { Citrate solution added to scrub section to } \\
\text { remove extracted sodium. } \\
\text { Citric acid used to strip strontium from organic, } \\
\text { done at pH }=1.5 \text { to } 2.0 \text { to separate strontium } \\
\text { from coextracted calcium. } \\
\text { Approximately } 95 \% \text { of the strontium present in } \\
\text { the feed was recovered with calcium being the } \\
\text { major contaminant. }\end{array}$ \\
\hline
\end{tabular}


Table A.3. (contd)

\begin{tabular}{|c|c|c|c|}
\hline $\begin{array}{c}\text { Literature } \\
\text { Source }\end{array}$ & Experimental Conditions ${ }^{(a)}$ & $D_{S r}{ }^{(b)}$ & Comments \\
\hline $\begin{array}{l}\text { Horner et al. } \\
\text { (1963) }\end{array}$ & $\begin{array}{l}0.2 \underline{\mathrm{M}} \text { HDEHP }+ \\
0.1 \underline{\mathrm{M}} \mathrm{NaDEHP}+ \\
0.15 \underline{\mathrm{M}} \text { TBP in } \\
\text { Amsco } 125-82 \\
\mathrm{pH}=4.5-6\end{array}$ & 9 & $\begin{array}{l}\text { Test conducted on PUREX simulated waste. } \\
\text { Tartrate added to feed to prevent precipitation of } \\
\text { iron. } \\
\text { Presence of } \mathrm{NaDEHP} \text { provides for a buffered } \\
\text { solvent, allowing better control of aqueous } \mathrm{pH} \text {. } \\
\text { Calcium, lanthanides and nickel are co- } \\
\text { extracted. } \\
\text { Scrubbing at } \mathrm{pH}=3-4 \text {, enhanced the separation } \\
\text { of sodium from strontium. } \\
\text { Strontium stripped, using } 1.5 \mathrm{M} \mathrm{HNO}_{3} \text {. } \\
\text { Counter-current demonstration tests on simulated } \\
\text { and actual PUREX waste were conducted with } \\
\text { strontium recovery of } 99.7 \% \text {. }\end{array}$ \\
\hline
\end{tabular}


Table A.3. (contd)

\begin{tabular}{|c|c|c|c|}
\hline $\begin{array}{l}\text { Literature } \\
\text { Source }\end{array}$ & Experimental Conditions $^{(a)}$ & $\mathrm{D}_{\mathrm{Sr}}{ }^{(\mathrm{b})}$ & Comments \\
\hline $\begin{array}{l}\text { Richardson } \\
\text { (1964) }\end{array}$ & $\begin{array}{l}0.14 \underline{\mathrm{M}} \text { HDEHP }+ \\
0.06 \underline{\mathrm{M}} \mathrm{NaDEHP}+ \\
0.2 \underline{\mathrm{M}} \mathrm{TBP} \text { in } \\
\text { Soltrol-170 } \\
\mathrm{pH}=4.7, \\
50^{\circ} \mathrm{C}\end{array}$ & $-\cdots$ & $\begin{array}{l}\text { Pilot studies were conducted in } 3 \text { " diameter } \\
\text { glass pulsed columns with PAW. } \\
\text { Over } 99 \% \text { of the strontium was extracted and } \\
\text { recovered in this pilot run. } \\
\text { The extraction was conducted a } 50^{\circ} \mathrm{C} \text { so that } \\
\text { cerium could be more efficiently extracted (i.e., } \\
\text { this was a process that was designed to extract } \\
\text { both strontium and lanthanides. }\end{array}$ \\
\hline \multicolumn{4}{|c|}{$\begin{array}{l}\text { The organic phase characteristics are given first, followed by the aqueous phase characteristics. } \\
D_{S r}=\text { strontium distribution coefficient: }[\mathrm{Sr}]_{\text {organic }} /[\mathrm{Sr}]_{\text {qqueous }} \text { at equilibrium for } 1 \text { batch contact. }\end{array}$} \\
\hline
\end{tabular}


Table A.4. Precipitation: Sodium Titanate

\begin{tabular}{|c|c|c|c|}
\hline $\begin{array}{l}\text { Literature } \\
\text { Source }\end{array}$ & Experimental Conditions & $D F_{S r}^{(a)}$ & Comments \\
\hline $\begin{array}{l}\text { Lee and Kilpatrick } \\
\text { (1982) }\end{array}$ & $\begin{array}{l}0.5 \mathrm{~g} / \mathrm{L} \text { sodium titanate, } \\
5 \times 10^{-7} \mathrm{M} \text { strontium, } \\
\text { alkaline solution, } \\
\text { contact time }=2 \text { days }\end{array}$ & $200-300$ & $\begin{array}{l}\text { Tests conducted on actual alkaline } \\
\text { supernatant waste. } \\
\text { Addition of sodium tetraphenylborate, } \\
\text { and sodium titanate as a slurry to } \\
\text { remove cesium, strontium, and } \\
\text { plutonium. } \\
\text { Solids/liquid separation made via cross- } \\
\text { flow filtration. }\end{array}$ \\
\hline $\begin{array}{l}\text { Martin et al. } \\
\text { (1984) }\end{array}$ & $\begin{array}{l}1.7 \times 10^{-3} \underline{\mathrm{M}}(0.5 \mathrm{~g} / \mathrm{l}) \text { sodium titanate, } \\
5 \times 10^{-7} \underline{\mathrm{M}} \text { strontium, } \\
\text { alkaline solution, } \\
\text { contact time }=2 \text { days }\end{array}$ & 200 & $\begin{array}{l}\text { Demonstration test conducted on actual } \\
\text { alkaline Savannah River waste. } \\
\text { Combined cesium/strontium removal } \\
\text { process via precipitation. }\end{array}$ \\
\hline
\end{tabular}


Table A.5. Precipitation: Ferric Hydroxide

\begin{tabular}{||l|l|c|l||}
\hline \multicolumn{1}{|c|}{$\begin{array}{c}\text { Literature } \\
\text { Source }\end{array}$} & \multicolumn{1}{|c|}{ Experimental Conditions } & $\mathrm{DF}_{\mathrm{Sr}}$ (a) & \multicolumn{1}{c||}{ Comments } \\
\hline $\begin{array}{l}\text { Pietrelli, Grossi, and } \\
\text { Troiani } \\
(1988)\end{array}$ & $\begin{array}{l}0.54 \mathrm{~g} / 1 \text { iron, } \\
\text { approx. } 5 \times 10^{-3} \mathrm{~g} / \text { liter strontium }\end{array}$ & $>100$ & $\begin{array}{l}\text { Tests conducted on actual 1AW-MTR } \\
\text { wastes. }\end{array}$ \\
\hline $\begin{array}{l}\text { Pietrelli and Troiani } \\
(1990)\end{array}$ & $\begin{array}{l}0.54 \mathrm{~g} / 1 \text { iron, } \\
\text { approx. } 5 \times 10^{-3} \mathrm{~g} / 1 \text { liter strontium }\end{array}$ & $>100$ & $\begin{array}{l}\text { Tests conducted on actual 1AW-MTR } \\
\text { wastes. }\end{array}$ \\
\hline $\begin{array}{l}\text { Grossi et al. } \\
(1992 \mathrm{a}, \mathrm{b})\end{array}$ & $\begin{array}{l}0.54 \mathrm{~g} / \mathrm{l} \text { iron, } \\
\text { approx. } 5 \times 10^{-3} \mathrm{~g} / \text { liter strontium }\end{array}$ & $>100$ & Tests conducted on a cold pilot scale. \\
\hline \multicolumn{1}{|c|}{$\mathrm{DF}_{\mathrm{Sr}}=$ strontium decontamination factor. } & \\
\hline
\end{tabular}


Table A.6. Precipitation: Other Precipitation Methods

\begin{tabular}{|c|c|c|c|}
\hline $\begin{array}{l}\text { Literature } \\
\text { Source }\end{array}$ & Experimental Conditions & $\mathrm{DF}_{\mathrm{Sr}}{ }^{\text {(a) }}$ & Comments \\
\hline \multicolumn{4}{|l|}{ Lead Sulfate } \\
\hline $\begin{array}{l}\text { Richardson } \\
\text { (1965) }\end{array}$ & $\begin{array}{l}0.02 \underline{\mathrm{M}} \text { lead nitrate, } \\
\text { sulfate }=0.67-3 \underline{\mathrm{M}} \text {, } \\
80^{\circ} \mathrm{C} \text {, } \\
\mathrm{pH}=0.4 \text { and } 4.0 .\end{array}$ & $95 \%$ Recovery & Pilot plant scale tests. \\
\hline \multicolumn{4}{|l|}{ Titanium Hydroxide } \\
\hline
\end{tabular}


Table A.6. (contd)

\begin{tabular}{|c|c|c|c|}
\hline $\begin{array}{c}\text { Literature } \\
\text { Source }\end{array}$ & Experimental Conditions & $\mathrm{DF}_{\mathrm{S}_{\mathrm{r}}}{ }^{(\mathrm{a})}$ & Comments \\
\hline \multicolumn{4}{|l|}{ Calcium Phosphate } \\
\hline $\begin{array}{l}\text { Gutman et al. } \\
\text { (1986) }\end{array}$ & 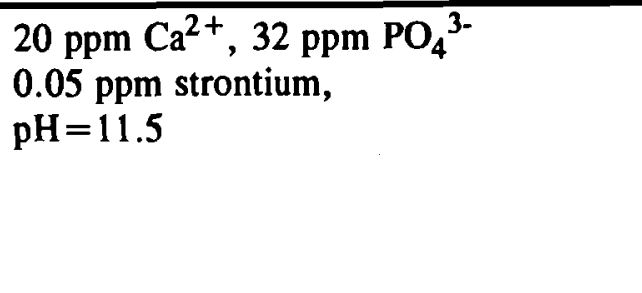 & 120 & $\begin{array}{l}\text { Studies conducted on contaminated } \\
\text { pond water. } \\
\text { Very fine precipitate formed. } \\
\text { Ultrafiltration showed improvement } \\
\text { over gravity or centrifugal separation. } \\
\text { Very sensitive to pH. }\end{array}$ \\
\hline $\begin{array}{l}\text { Carley-Macauly et al. } \\
\text { (1981) }\end{array}$ & $\begin{array}{l}\text { Calcium phosphate (or iron phosphate) } \\
\mathrm{pH}>11 \\
\text { Calcium carbonate } \\
\mathrm{pH}=10.5 \\
\text { Barium Sulfate } \\
\mathrm{pH}>8.5 \\
\begin{array}{l}\text { Manganese dioxide } \\
\mathrm{pH}>11\end{array}\end{array}$ & $>100$ & \\
\hline
\end{tabular}


Table A.7. Ion Exchange: Polyantimonic Acid

\begin{tabular}{|c|c|c|c|}
\hline $\begin{array}{l}\text { Literature } \\
\text { Source }\end{array}$ & Experimental Conditions & $\begin{array}{c}\text { Strontium } \\
\text { Separation } \\
\text { Performance }\end{array}$ & Comments \\
\hline $\begin{array}{l}\text { Baetsle et al. } \\
\text { (1965) }\end{array}$ & $\begin{array}{l}7 \mathrm{~g} \text { polyantimonic acid, } \\
50-100 \text { mesh, } \\
\text { column height }=10.4 \mathrm{~cm} \text {, } \\
\text { column diameter }=1 \mathrm{~cm} \text {, } \\
62.5 \mathrm{mg} / \text { liter strontium, } \\
0.2 \mathrm{ml} / \mathrm{min}, \\
2 \underline{\mathrm{M} \mathrm{HNO}}{ }_{3}, \\
60^{\circ} \mathrm{C} \text {. }\end{array}$ & $\mathrm{DF}_{\mathrm{Sr}}^{(\mathrm{a})}=1000$ & $\begin{array}{l}\text { Kinetic studies showed that } t_{1 / 2}=2 \text { to } 3 \\
\text { hours. } \\
\text { Addition of } \mathrm{Na}_{2} \mathrm{SiO}_{3} \text { reduced } \mathrm{t}_{1 / 2} \text { to } \\
1.5 \text { hours. } \\
50 \% \mathrm{Sr} \text { leakage through the column } \\
\text { occurred at } 450 \text { bed volumes under } \\
\text { experimental conditions given. }\end{array}$ \\
\hline
\end{tabular}


Table A.7. (contd)

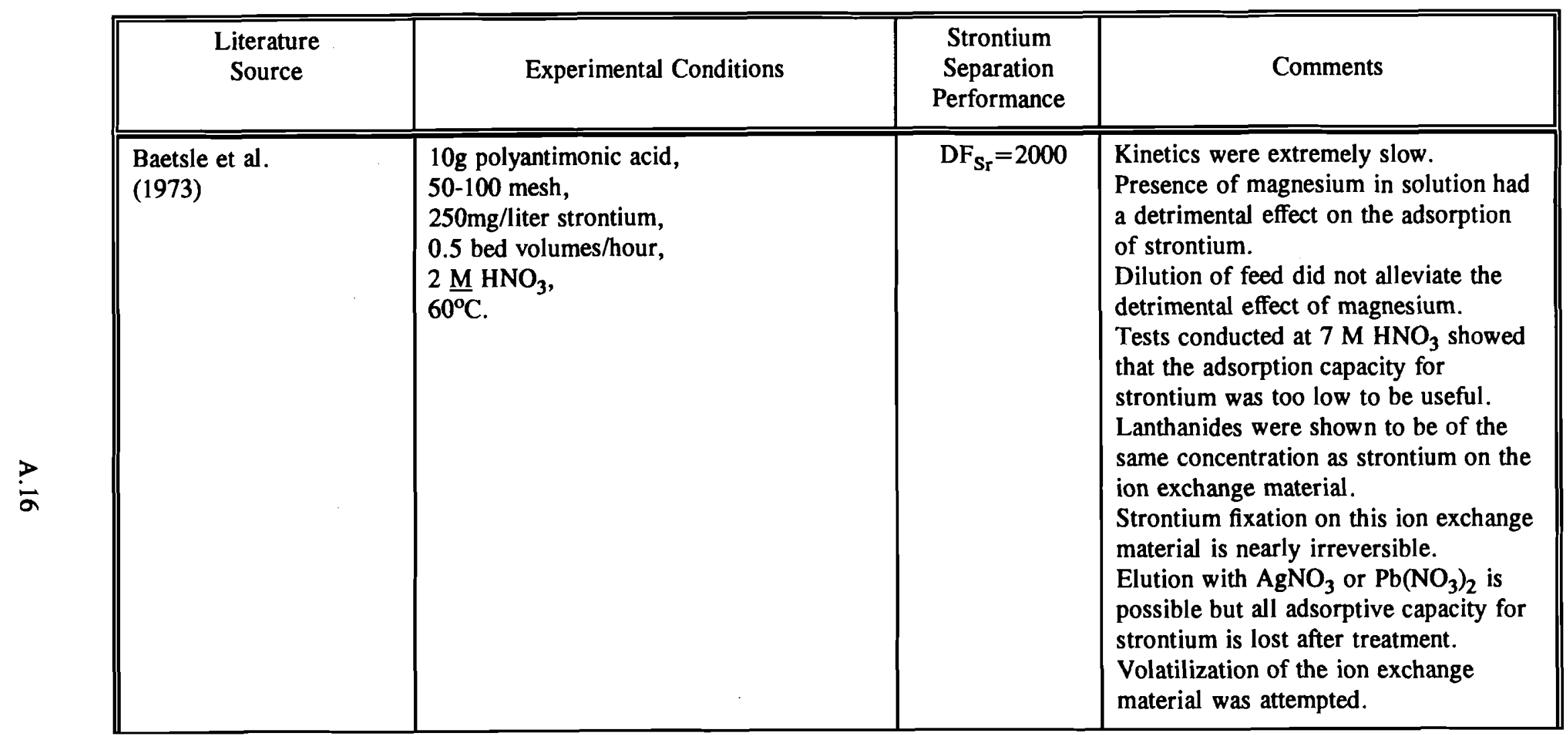


Table A.7. (contd)

\begin{tabular}{|c|c|c|c|}
\hline $\begin{array}{l}\text { Literature } \\
\text { Source }\end{array}$ & Experimental Conditions & $\begin{array}{c}\text { Strontium } \\
\text { Separation } \\
\text { Performance }\end{array}$ & Comments \\
\hline $\begin{array}{l}\text { McKee et al. } \\
(1983)\end{array}$ & $\begin{array}{l}2.0 \underline{\mathrm{M}} \mathrm{HNO}_{3} \\
\text { flow }=0.2 \text { column volumes/hour } \\
50^{\circ} \mathrm{C}\end{array}$ & --- & $\begin{array}{l}\text { Tests conducted with simulated high } \\
\text { level waste. } \\
1 \% \text { strontium breakthrough after } 23 \\
\text { column volumes. } \\
50 \% \text { strontium breakthrough after } 30 \\
\text { column volumes. } \\
\text { At } 50 \% \text { breakthrough, loading = } \\
\text { breakthrough } 0.0185 \mathrm{~g} \mathrm{Sr/g} \text { sorber. } \\
\text { Strontium breakthrough was extremely } \\
\text { sensitive to flow rate through column, } \\
\text { e.g., in larger column tests, by } \\
\text { increasing the flowrate from } 0.5 \\
\text { column volumes/hr to } 1 \text { column } \\
\text { volume/hr, strontium breakthrough } \\
\text { increased from approximately } 0.3 \% \text { to } \\
30 \% \text {. } \\
\text { System exhibits slow kinetics. }\end{array}$ \\
\hline
\end{tabular}


Table A.7. (contd)

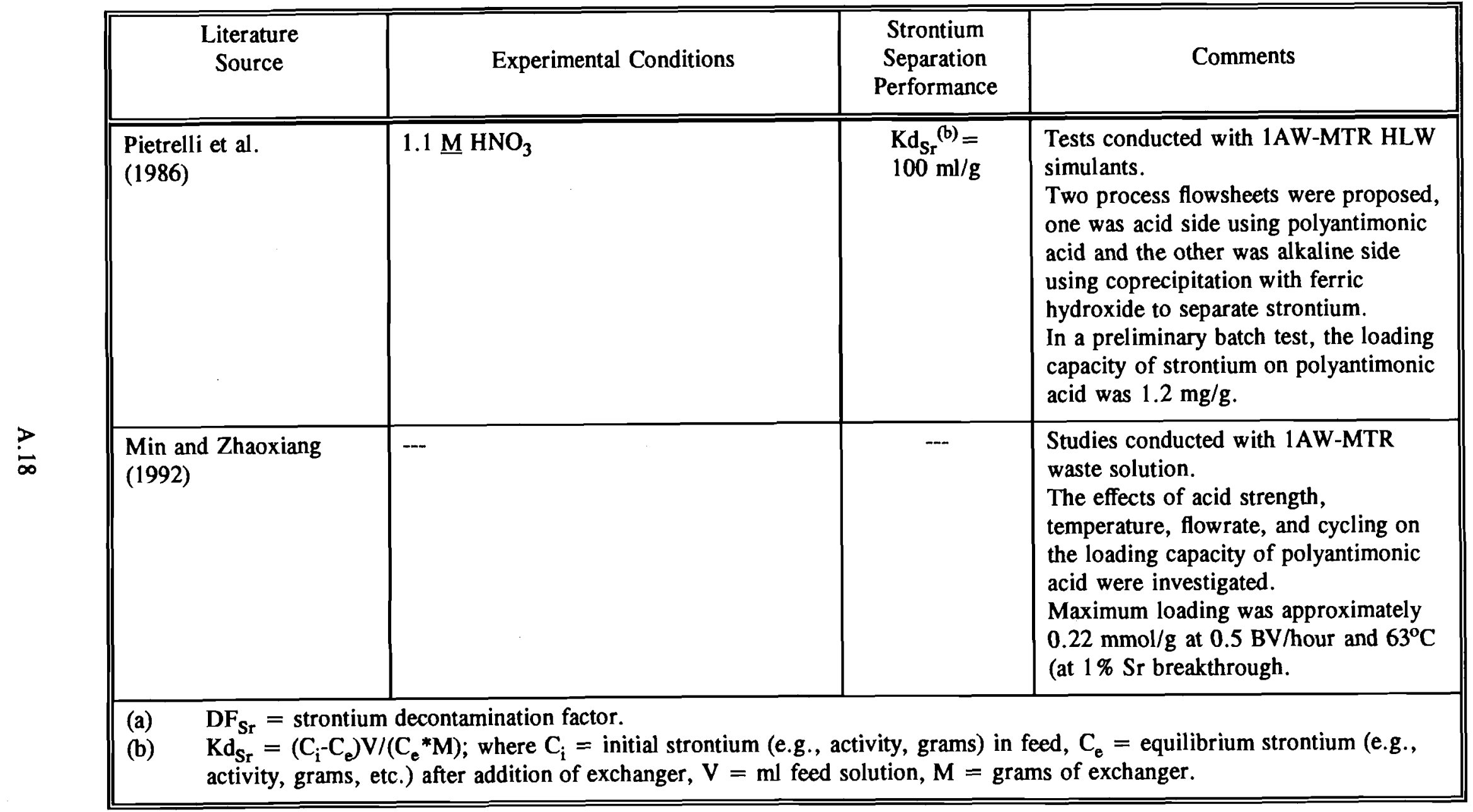


Table A.8. Ion Exchange: Sodium Titanate

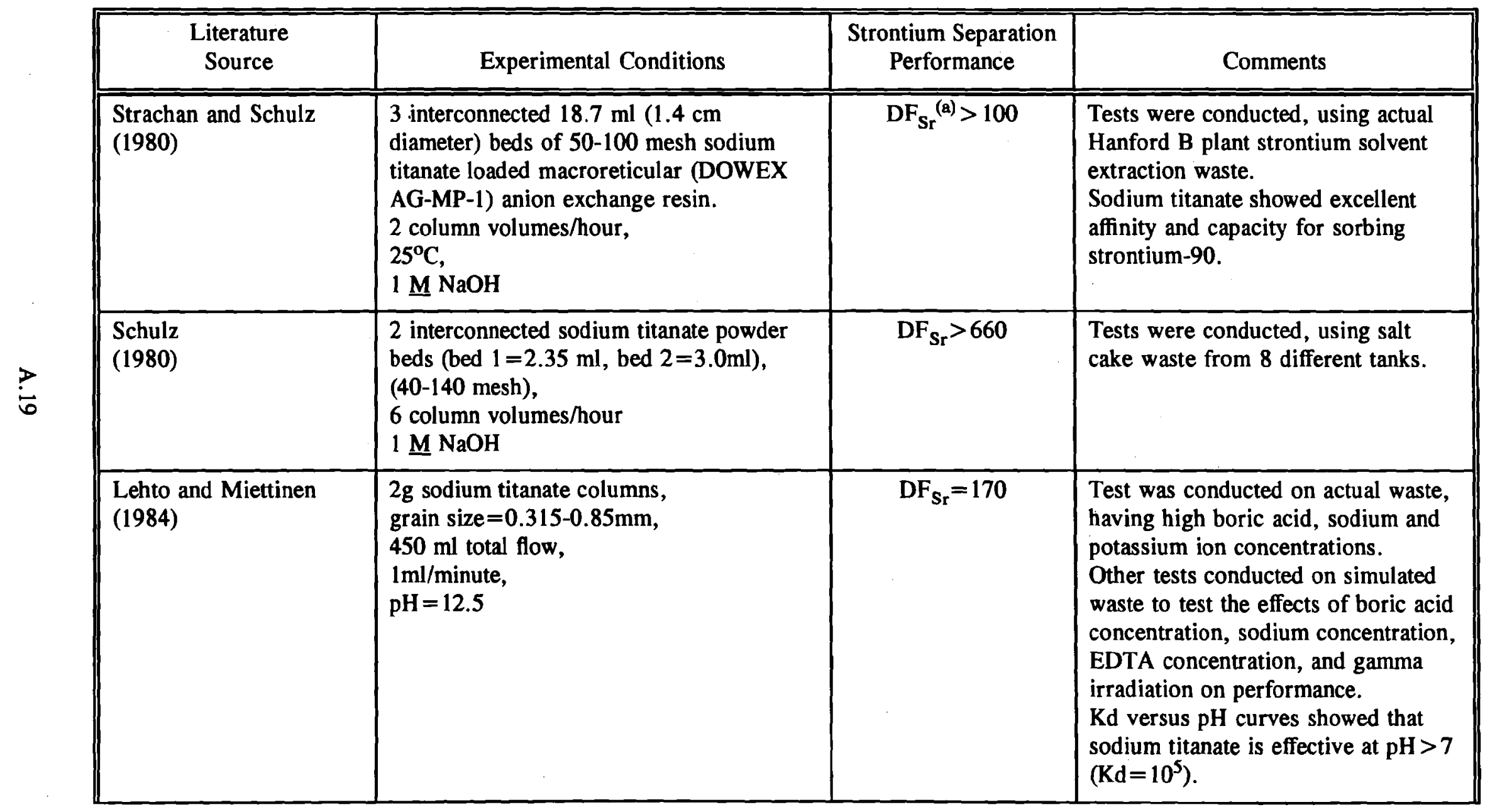


Table A.8. (contd)

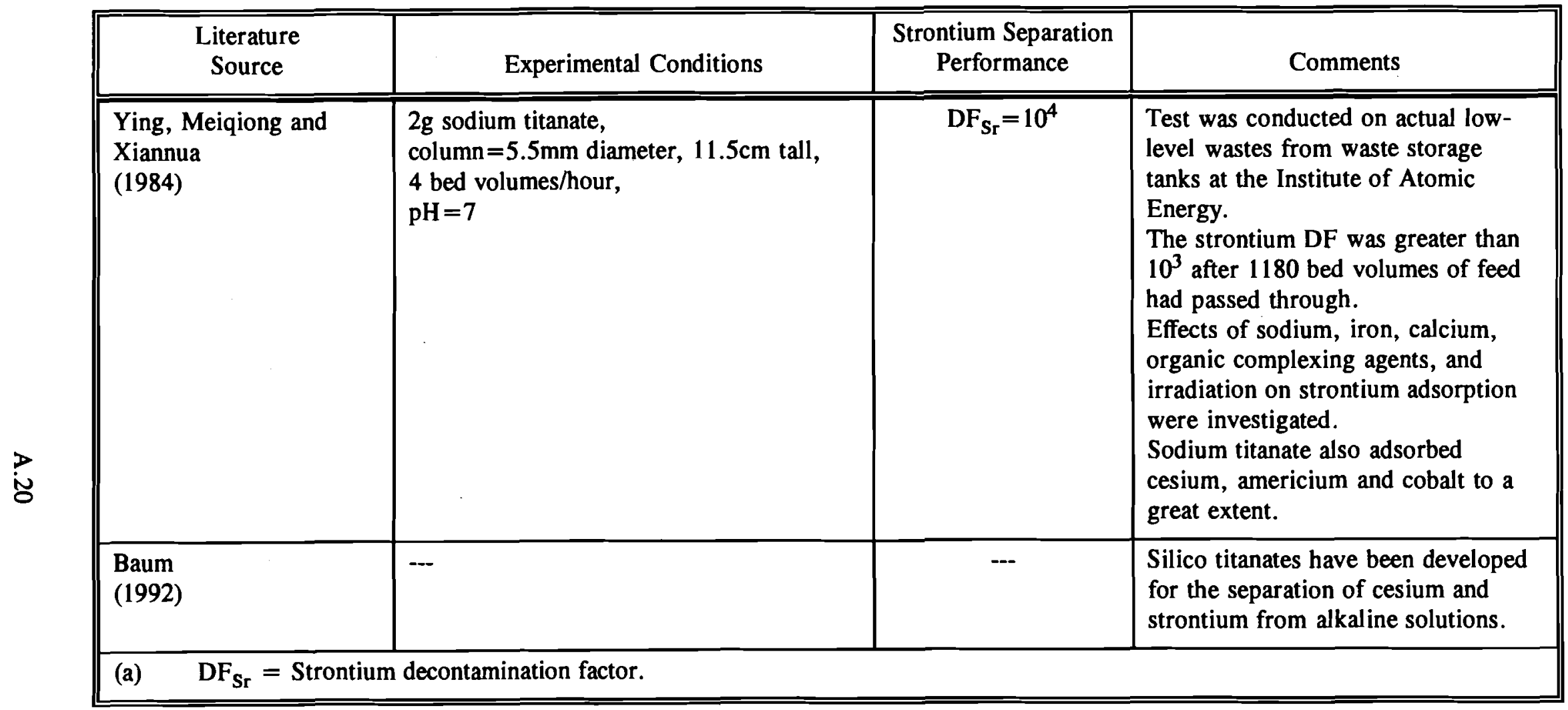


Table A.9. Ion Exchange: Macrocyclic Ligands

\begin{tabular}{|c|c|c|c|}
\hline $\begin{array}{l}\text { Literature } \\
\text { Source }\end{array}$ & Experimental Conditions & $\begin{array}{c}\text { Strontium } \\
\text { Separation } \\
\text { Performance }\end{array}$ & Comments \\
\hline $\begin{array}{l}\text { Horwitz, Chiarizia and } \\
\text { Fisher } \\
\text { (1992) }\end{array}$ & $\begin{array}{l}1 \underline{\mathrm{M}} 4,4^{\prime}\left(5^{\prime}\right) \text {-bis(tert-butylcyclohexano)- } \\
18 \text {-crown-6 in } 1 \text {-octanol sorbed onto } \\
\text { Amberlite XAD-7, } \\
0.01 \underline{\mathrm{M} \mathrm{HNO}} \mathrm{HN}_{3} \text { to } 10 \mathrm{MNO} \mathrm{HNO}_{3}\end{array}$ & -- & $\begin{array}{l}\text { Barium was retained on the resin. } \\
\text { No alkali metals were significantly } \\
\text { retained on the resin. } \\
\text { Lead was retained more strongly than } \\
\text { was strontium. } \\
\text { Tetravalent plutonium, neptunium and } \\
\text { polonium are retained by the resin. } \\
\text { Strontium retention increased with } \\
\text { increasing } \mathrm{HNO}_{3} \text {. }\end{array}$ \\
\hline $\begin{array}{l}\text { Chiarizia, Horwitz and } \\
\text { Fisher } \\
\text { (1992) }\end{array}$ & - & --- & $\begin{array}{l}\text { This study compared calculated versus } \\
\text { experimental acid dependencies and } \\
\text { extraction constants. }\end{array}$ \\
\hline
\end{tabular}


Table A.9. (contd)

\begin{tabular}{|c|c|c|c|}
\hline $\begin{array}{l}\text { Literature } \\
\text { Source }\end{array}$ & Experimental Conditions & $\begin{array}{c}\text { Strontium } \\
\text { Separation } \\
\text { Performance }\end{array}$ & Comments \\
\hline $\begin{array}{l}\text { Horwitz, Fisher and } \\
\text { Chiarizia } \\
(1992)\end{array}$ & $\begin{array}{l}1 \underline{\mathrm{M}} 4,4^{\prime}\left(5^{\prime}\right) \text {-bis(tert-butylcyclohexano)- } \\
18 \text {-crown-6 in 1-octanol sorbed onto } \\
\text { Amberlite XAD-7, } \\
3 \underline{\mathrm{M} \mathrm{HNO}_{3}} \text {. }\end{array}$ & $\begin{array}{l}\text { Sr separation } \\
\text { from } \mathrm{Al}=100 \text {, } \\
\text { Sr separation } \\
\text { from } \mathrm{Ca}=10^{5} \text {. }\end{array}$ & $\begin{array}{l}\text { Tests conducted on synthetic nuclear } \\
\text { waste that simulated the dissolved } \\
\text { Hanford sludge. }\end{array}$ \\
\hline $\begin{array}{l}\text { Camaioni, Colton and } \\
\text { Bruening } \\
\text { (1992) }\end{array}$ & $\begin{array}{l}10 \mathrm{~g} \text { Superlig } 601, \\
30 \text { bed volumes, } \\
5 \underline{\mathrm{M} \mathrm{HNO}} 3\end{array}$ & $\begin{array}{c}\mathrm{DF}_{\mathrm{Sr}_{\mathrm{r}}}=100 \text { in } \\
\text { first } 20 \text { bed } \\
\text { volumes of feed }\end{array}$ & $\begin{array}{l}\text { Tests conducted on synthetic waste that } \\
\text { simulated PUREX raffinate. } \\
\text { Nearly complete breakthrough occurred } \\
\text { after } 30 \text { bed volumes of feed. } \\
\text { Approximately } 35 \% \text { of the strontium } \\
\text { and barium was eluted with a } 1 \mathrm{M} \\
\mathrm{HNO}_{3} \text { wash followed by a } \mathrm{Na}_{3} \text { citrate } \\
\text { wash, the remainder was eluted with } \\
\mathrm{Na}_{4} \text { EDTA wash. }\end{array}$ \\
\hline $\begin{array}{l}\text { Lumetta et al. } \\
\text { (1993) }\end{array}$ & \begin{tabular}{l}
$0.494 \mathrm{~g} \mathrm{Sr}-\mathrm{Spec}$, \\
column diameter $=5 \mathrm{~mm}$, \\
column height $=73 \mathrm{~mm}$, \\
$0.2 \mathrm{ml} / \mathrm{min}$, \\
$3.5 \underline{\mathrm{M} \mathrm{HNO}} 3$ \\
\hdashline $0.407 \mathrm{~g}$ Superlig 601, \\
column diameter $=7 \mathrm{~mm}$, \\
column height $=24 \mathrm{~mm}$, \\
$1.5 \mathrm{ml} / \mathrm{min}$, \\
$3.5 \underline{\mathrm{M} \mathrm{HNO}} 3$
\end{tabular} & $\begin{array}{c}\text { No } \mathrm{Sr} \text { detected in } \\
\text { effluent during } \\
\text { loading } \\
\text { (7 column } \\
\text { volumes) } \\
-\mathrm{DF}_{\mathrm{Sr}}=20 \\
\text { in } 17 \text { column } \\
\text { volumes of feed }\end{array}$ & $\begin{array}{l}\text { Tests conducted on actual Hanford } \\
\text { NCRW. } \\
\text { Sr-Spec and Superlig } 601 \text { were } \\
\text { evaluated for the separation of } \\
\text { strontium. }\end{array}$ \\
\hline
\end{tabular}


Table A.10. Ion Exchange: Other Ion Exchangers

\begin{tabular}{|c|c|c|c|}
\hline $\begin{array}{l}\text { Literature } \\
\text { Source }\end{array}$ & Experimental Conditions & $\begin{array}{c}\text { Strontium } \\
\text { Separation } \\
\text { Performance }\end{array}$ & Comments \\
\hline \multicolumn{4}{|c|}{ DOWEX 50W, X12 } \\
\hline $\begin{array}{l}\text { Bray et al. } \\
\text { (1961) }\end{array}$ & $\begin{array}{l}\text { DOWEX 50W, X12 } \\
(50-100 \text { mesh) }\end{array}$ & $\begin{array}{l}98 \% \text { pure } S r \\
\text { product }\end{array}$ & $\begin{array}{l}\text { Organic exchanger, used on large scale } \\
\text { to produce a strontium product for use } \\
\text { as a power source. }\end{array}$ \\
\hline $\begin{array}{l}\text { Bray et al. } \\
(1984)\end{array}$ & $\begin{array}{l}\text { IRC- } 718, \\
7 \text { day contact time, } \\
\text { pH=10 }\end{array}$ & $\mathrm{Kd}_{\mathrm{Sr}}^{(\mathrm{a})}=1500$ & $\begin{array}{l}\text { Batch tests conducted on simulated } \\
\text { West Valley alkaline waste. } \\
\text { Organic macroporous cation exchanger. } \\
\text { At } \mathrm{pH}=13, \mathrm{Kd}=177^{(\mathrm{a})} \text {. } \\
\text { Flow tests showed that strontium } \\
\text { separation performance was dependent } \\
\text { on feed } \mathrm{pH} \text {. } \\
\text { Strontium eluted with } 2 \mathrm{M} \mathrm{HCOOH} \text {. }\end{array}$ \\
\hline
\end{tabular}


Table A.10. (contd)

\begin{tabular}{|c|c|c|c|}
\hline $\begin{array}{l}\text { Literature } \\
\text { Source }\end{array}$ & Experimental Conditions & $\begin{array}{c}\text { Strontium } \\
\text { Separation } \\
\text { Performance }\end{array}$ & Comments \\
\hline $\begin{array}{l}\text { Johnson } \\
\text { (1985) }\end{array}$ & $\begin{array}{l}\text { Duolite ES-286 } \\
\mathrm{pH}=8.0\end{array}$ & $\begin{array}{l}1.4 \times 10^{-5} \text { moles } \mathrm{Sr} \\
\text { absorbed } / \mathrm{gm} \text { resin }\end{array}$ & $\begin{array}{l}\text { Batch comparison tests between } \\
\text { Duolite ES-286, Duolite ES-278, } \\
\text { DOWEX 50W, X-8, and Amberlite } \\
\text { IRC-718 conducted, using simulated } \\
\text { waste. Duolite ES-286 showed superior } \\
\text { Sr removal compared to other ion } \\
\text { exchangers. } \\
\text { Column eluted, using } 2-3 \mathrm{M} \\
\text { nitric acid or ammonium nitrate. } \\
\text { Chemically/radiolytically stable. } \\
\text { Addition of EDTA is necessary to } \\
\text { separate Sr from lanthanides and other } \\
\text { alkaline earth metals. }\end{array}$ \\
\hline $\begin{array}{l}\text { Carley-Macauly et al. } \\
\text { (1981) }\end{array}$ & $\begin{array}{l}\mathrm{CS}-100 \\
\mathrm{pH}=11.8\end{array}$ & $\mathrm{DF}_{\mathrm{Sr}}{ }^{(\mathrm{b})}=800$ & $\begin{array}{l}\text { Pilot plant runs on LLW. } \\
\text { Interfering bulk cations are removed } \\
\text { from solution upstream of the ion } \\
\text { exchange process via precipitation by } \\
\text { adjusting the feed } \mathrm{pH}=11.8 \text {. } \\
\text { Column eluted, using } 0.5 \underline{\mathrm{M}} \\
\text { nitric acid. }\end{array}$ \\
\hline
\end{tabular}


Table A.10. (contd)

\begin{tabular}{|c|c|c|c|}
\hline $\begin{array}{l}\text { Literature } \\
\text { Source }\end{array}$ & Experimental Conditions & $\begin{array}{c}\text { Strontium } \\
\text { Separation } \\
\text { Performance }\end{array}$ & Comments \\
\hline $\begin{array}{l}\text { Campbell, Lee and } \\
\text { Dillow. } \\
\text { (1990) }\end{array}$ & $\begin{array}{l}\mathrm{CS}-100 \\
\mathrm{pH}=12.5\end{array}$ & $\mathrm{Kd}_{\mathrm{Sr}}=5000$ & $\begin{array}{l}\text { Batch tests conducted on simulated } \\
\text { LLW. } \\
\text { The presence of sodium decreased the } \\
\text { strontium Kd. } \\
\text { The presence of potassium had little } \\
\text { effect on strontium separation. } \\
\text { The Savannah River resorcinol resin } \\
\text { also showed some affinity for } \\
\text { strontium, although not as much as CS- } \\
100 \text {. }\end{array}$ \\
\hline
\end{tabular}


Table A.10. (contd)

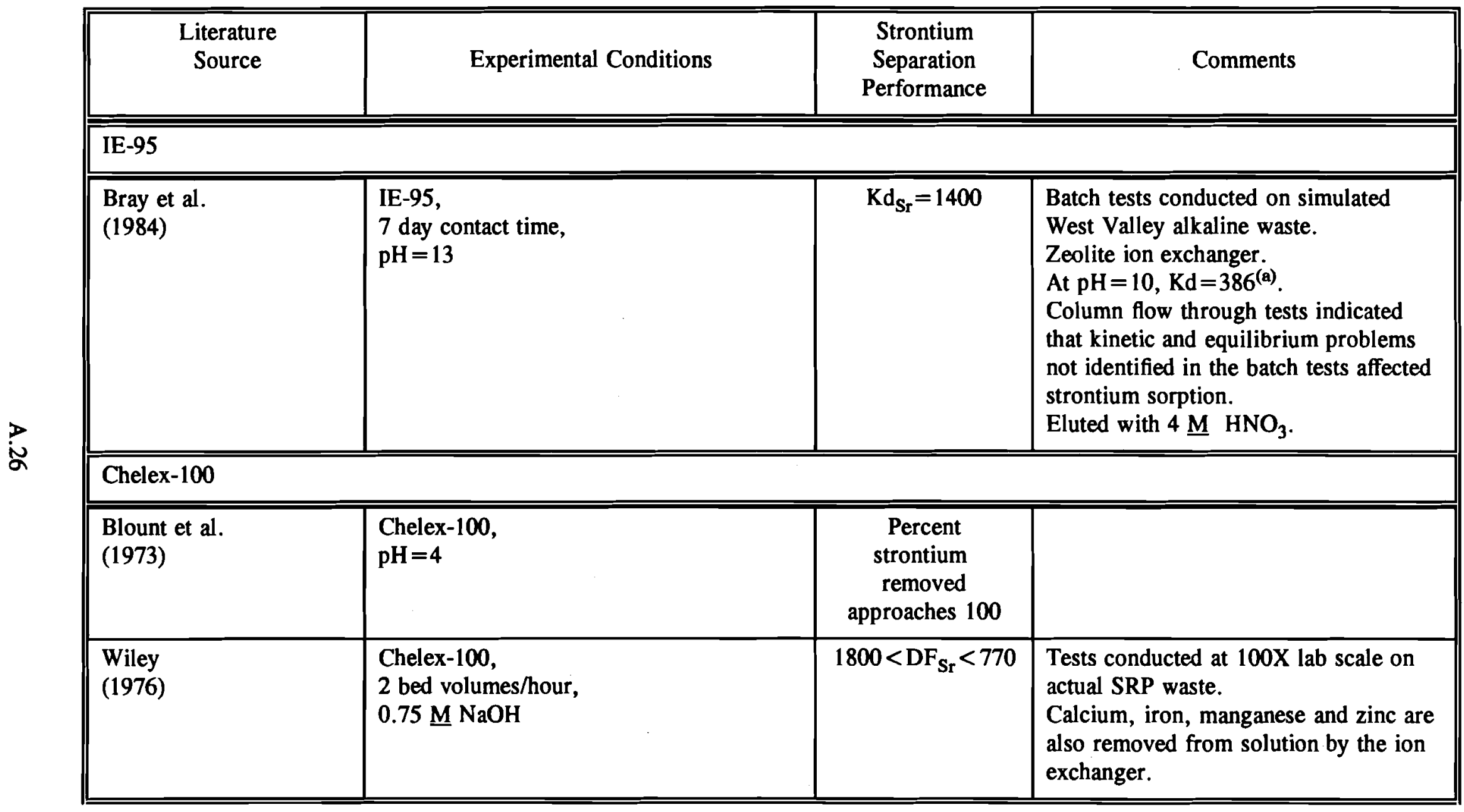


Table A.10. (contd)

\begin{tabular}{|c|c|c|c|}
\hline $\begin{array}{l}\text { Literature } \\
\text { Source }\end{array}$ & Experimental Conditions & $\begin{array}{l}\text { Strontium } \\
\text { Separation } \\
\text { Performance }\end{array}$ & Comments \\
\hline $\begin{array}{l}\text { Phillips et al. } \\
\text { (1984) }\end{array}$ & $\mathrm{pH}=2-10$ & $\mathrm{DF}_{\mathrm{S}_{\mathrm{r}}}>100$ & Batch contact experiments. \\
\hline \multicolumn{4}{|l|}{ Manganese Oxide } \\
\hline $\begin{array}{l}\text { Hooper } \\
\text { (1985) }\end{array}$ & $\mathrm{pH}=8-10$ & $\mathrm{DF}_{\mathrm{Sr}_{\mathrm{r}}}>100$ & $\begin{array}{l}\text { Batch contact experiments. } \\
\text { Resistant to radiation damage. }\end{array}$ \\
\hline \multicolumn{4}{|l|}{ Hydrous Titanium Oxide } \\
\hline $\begin{array}{l}\text { Hooper } \\
\text { (1985) }\end{array}$ & $\mathrm{pH}=10$ & $\mathrm{DF}_{\mathrm{Sr}_{\mathrm{r}}}>100$ & $\begin{array}{l}\text { Batch contact experiments. } \\
\text { Resistant to radiation damage. }\end{array}$ \\
\hline \multicolumn{4}{|l|}{$\mathrm{Na}_{4} \mathrm{Mg}_{6} \mathrm{Al}_{4} \mathrm{Si}_{4} \mathrm{O}_{20} \mathrm{~F}_{4}$ mica } \\
\hline $\begin{array}{l}\text { Paulus, Komarneni, and } \\
\text { Roy } \\
(1992)\end{array}$ & $\begin{array}{l}8 \times 10^{-4} \mathrm{~g} / \mathrm{ml} \mathrm{Na}_{4} \mathrm{Mg}_{6} \mathrm{Al}_{4} \mathrm{Si}_{4} \mathrm{O}_{20} \mathrm{~F}_{4} \text { mica } \\
6 \times 10^{-4}-3.7 \times 10^{-3} \mathrm{~N} \mathrm{SrCl}_{2}\end{array}$ & -- & $\begin{array}{l}\text { Batch contact experiments. } \\
\text { Results indicated that strontium could } \\
\text { be removed from high sodium streams. }\end{array}$ \\
\hline \multicolumn{4}{|c|}{$\begin{array}{l}\mathrm{Kd}_{S_{r}}=\left(C_{i}-C_{e}\right) V /\left(C_{e}{ }^{*} M\right) ; \text { where } C_{i}=\text { initial strontium (e.g., activity, grams, etc.) in feed, } C_{e}=\text { equilibrium strontium } \\
(\text { e.g., activity, grams, etc.) after addition on exchanger, } V=\text { ml feed solution, } M=\text { grams of exchanger. } \\
D_{S r}=\text { strontium decontamination factor. }\end{array}$} \\
\hline
\end{tabular}


PNL-9053

UC-721

\section{Distribution}

No. of

Copies

Offsite

12 DOE Office of Scientific and Technical Information

Onsite

4 DOE Richland Operations

S. T. Burnum

R3-74

P. E. Lamont

R3-74

R. L. Higgins

R3-74

M. L. Ramsay

B5-24

11 Westinghouse Hanford Company

J. N. Appel

S. A. Barker

S4-58

W. B. Barton

S4-55

L4-75

G. B. Bazinet

R. A. Kirkbride

M. J. Klem

W. C. Miller

R. M. Orme

R. C. Roal

D. G. Sutherland

D. J. Washenfelder
No. of

Copies

42 Pacific Northwest Laboratory

C. R. Allen

P7-43

E. G. Baker

L. A. Bray

K. P. Brooks

L. R. Bunnell

C. D. Carlson

N. G. Colton

M. A. Gerber

E. J. Hirschi

L. K. Holton

B. M. Johnson

E. O. Jones

D. E. Kurath (10)

J. P. LaFemina

G. J. Lumetta

S. J. Mitchell

R. J. Orth (5)

J. L. Ryan

A. J. Schmidt

L. J. Sealock, Jr.

G. J. Sevigny

J. L. Swanson

K. M. Tominey

Publishing Coordination

Technical Report Files (5)
P8-38

P7-25

P7-43

P8-44

P7-25

P8-30

P8-38

P7-18

P7-43

K1-78

P8-30

P7-43

K2-12

P7-25

K7-94

P8-30

P7-25

K2-40

K2-10

P7-43

P7-25

K7-97

Dist.1 